\title{
Investigation of Lung Involvement in Connective Tissue Disorders
}

\author{
Spyros A. Papiris ${ }^{a}$ Effrosyni D. Manali ${ }^{a}$ Likurgos Kolilekas $^{b}$ \\ Konstantinos Kagouridis ${ }^{a}$ Maria Maniati ${ }^{a}$ Raphael Borie ${ }^{d}$ Pauline Pradere $^{d}$ \\ Bruno Crestani $^{d}$ Demosthenes Bouros ${ }^{c}$ \\ a 2nd Department of Pneumonology, 'Attikon' University Hospital, Athens Medical School, National and

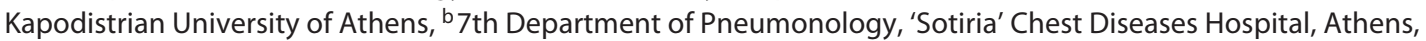 \\ and ' 1 st Department of Pneumonology, 'Sotiria' Chest Diseases Hospital, Athens Medical School, National and \\ Kapodistrian University of Athens, Athens, Greece; ${ }^{d}$ DHU FIRE, Service de Pneumologie A, Centre de compétence \\ des maladies pulmonaires rares, INSERM, Unité 1152, Hôpital Bichat, APHP, Université Paris-Diderot, Paris, France
}

\section{Key Words}

Rheumatoid arthritis · Systemic lupus erythematosus .

Systemic sclerosis · Dermatomyositis-polymyositis · Primary Sjögren's syndrome · Mixed connective tissue disease · Ankylosing spondylitis · Pleuritis · Fibrotic nonspecific interstitial pneumonia - Usual interstitial pneumonia-type pulmonary fibrosis - Infections . Pulmonary embolism . Diffuse alveolar hemorrhage - Pulmonary arterial hypertension - Bronchiolitis - Apical fibrobullous disease

\footnotetext{
Abstract

Lung involvement in connective tissue disorders (CTDs) may present as pleomorphic since any lung compartment may be involved such as airways, exocrine secretory and alveolar epithelia, interstitial lung structure, pulmonary vasculature and pleura as well as, in specific disorders, several tissues of the thoracoabdominal ventilator pump. Any combination of the above anatomic structures may be involved concomitantly although some specific combinations may include a determinant of rheumatic disorders. The diagnosis of a specific CTD requires the fulfilment of clearly defined clinical and laboratory criteria including in most cases positivity for autoantibodies, mostly specific serologic combinations. In this setting, serologic investigation targets mainly, although not ex-
}

clusively, the detection of antinuclear antibodies. A specific serologic positivity or a combination of autoantibodies constitutes not only a diagnostic criterion for a specific CTD, but may also characterize the pattern of respiratory manifestation in a determinant rheumatic disorder. Therefore, the investigation of lung involvement in CTDs requires adequate skills in the ambit of a multidisciplinary approach and an extended spectrum of diagnostic tools and modalities able to detect both early clinical clues and serologic conversion as well as any pathophysiologic alteration that regards the complexity of respiratory functional status. Although many patients with CTDs suffer from a 'vicious' combination of lung involvement, lung drug toxicity and infections related to the above two as well as to the 'mater' disease, for space reasons this review will focus on the established lung manifestations that regard the 7 major CTDs.

(c) 2015 S. Karger AG, Basel

\section{Introduction}

Lung involvement in connective tissue disorders (CTDs) is common and constitutes a major determinant of morbidity and mortality $[1,2]$. In this setting lung disease may present as pleomorphic, since any lung com-

\section{KARGER 125}

C 2015 S. Karger AG, Basel

0025-7931/15/0901-0002\$39.50/0

E-Mail karger@karger.com

www.karger.com/res
Spyros A. Papiris, Professor of Medicine

Head 2nd Department of Pneumonology, 'Attikon' University Hospital

1 Rimini Street

GR-12462 Haidari (Greece)

E-Mail papiris@ otenet.gr 
partment may be involved such as the airways, exocrine secretory and alveolar epithelia, interstitial lung structure, pulmonary vasculature and pleura as well as several tissues of the thoracoabdominal ventilator pump in specific disorders [1-3]. Furthermore, any combination of the above anatomic structures may be involved concomitantly [4] although some specific combinations may include a determinant of rheumatic disorders $[1,5]$. Among the different respiratory manifestations in CTDs, the usual interstitial pneumonia (UIP) pattern of pulmonary fibrosis (PF), the development of pulmonary arterial hypertension (PAH), pulmonary embolism and diffuse alveolar hemorrhage (DAH) appear to be those most severely affecting a patient's prognosis [6-13]. The diagnosis of a specific autoimmune rheumatic disorder requires the fulfilment of clearly defined clinical and laboratory criteria including in most cases positivity for autoantibodies, mostly specific serologic combinations. In this setting, serologic investigation mainly targets, although not exclusively, the detection of antinuclear antibodies (ANAs) [14]. ANAs are of two main categories: (1) those against single- and double-stranded DNA diagnostic for systemic lupus erythematosus (SLE) and against histones diagnostic for pharmacologic SLE, and (2) those against extractable nuclear antigens including anti-Smith antigen antibodies, antiribonucleoprotein, SSA/Ro, SSA/ La, anti-DNA-topoisomerase-I (Scl-70), anti-histidyltransfer RNA (tRNA) synthetase (Jo-1) and several others, specific for the diagnosis of different CTDs (table 1) [15]. Furthermore, a specific serologic positivity or a combination of autoantibodies constitutes not only a diagnostic criterion for a specific CTD but may also characterize a specific pattern of respiratory manifestation in a determinant rheumatic disorder [16] (table 1). Therefore, the investigation of lung involvement in rheumatic diseases requires adequate skills more than the ambit of a multidisciplinary approach and an extended spectrum of diagnostic tools and modalities able to detect both early clinical clues and serologic conversion as well as any pathophysiologic alteration that regards the complexity of respiratory functional status $[17,18]$.

In most cases lung involvement follows the diagnosis of a specific CTD while in a minority lung disease precedes the establishment of undisputed diagnostic criteria of a specific rheumatic disorder. In some cases lung involvement and especially interstitial lung disease (ILD) present in the setting where established diagnostic criteria for a specific rheumatic disorder never met, though serology for autoantibodies, inflammatory biomarkers, clinical clues and some histopathology features may be

Lung Involvement in Rheumatologic Disease indicative but not sufficient for a specific rheumatic disorder $[5,19,20]$. In this setting the old practice to treat fibrotic idiopathic ILDs by immunosuppressants may further delay the attainment of specific rheumatic disease criteria [21], a fact that might affect the natural history of the disease and also influence therapeutic decisions and prognosis [22].

Although many patients with CTDs suffer from a 'vicious' combination of lung involvement, lung drug toxicity and infections related to the above two as well as to the 'mater' disease, for space reasons this review will focus on the established lung manifestations that regard the $7 \mathrm{ma}-$ jor autoimmune rheumatic disorders otherwise called CTDs, i.e. rheumatoid arthritis (RA), SLE, systemic sclerosis (SS), dermatomyositis-polymyositis (DM-PM), primary Sjögren's syndrome (pSs), mixed connective tissue disease (MCTD) and ankylosing spondylitis.

\section{Rheumatoid Arthritis}

RA is the most common of the CTDs mentioned above and constitutes a systemic inflammatory disorder affecting mainly and mostly symmetrically and concomitantly several small but also large joints by a progressive erosive arthritis leading to articular deformities and severe dysfunction [23]. Although the etiopathogenesis of the disease is not fully understood, RA is considered an autoimmune disease, and patients with the disease present circulating autoantibodies, mainly rheumatoid factor (RF), an autoantibody against the $\mathrm{Fc}$ fragment of the IgG antibodies, and anti-cyclic citrullinated peptide antibodies [24]. Extra-articular systemic manifestations are not uncommon, and among them a major determinant of morbidity and mortality are respiratory manifestations $[25,26]$ (see online suppl. table 1; for all online suppl. material, see www.karger.com/doi/10.1159/000435817). In RA - although any respiratory compartment may be affected ILDs, pleural disease and bronchiectasis are most commonly observed [27].

\section{Interstitial Lung Disease}

ILD may occur commonly in RA although its exact prevalence determination is influenced by the methodology applied (clinical, physiological, imaging and/or histopathology approach) [28]. At any case in RA the most commonly occurring ILD is UIP-type PF (see online suppl. fig. 1a-c) in contrast to the other CTDs where the most frequent ILD involvement appears to be the fibrotic nonspecific interstitial pneumonia (f-NSIP) pattern $[8$, 
Table 1. Immunofluorescence nuclear pattern, specific nuclear antigens and nonantinuclear autoantibodies in CTDs and their relation with pulmonary involvement

\begin{tabular}{|c|c|c|c|c|c|c|}
\hline & $\mathrm{RA}$ & SLE & Scleroderma & DM-PM & $\begin{array}{l}\text { Sjögren's } \\
\text { syndrome }\end{array}$ & MCTD \\
\hline \multicolumn{7}{|c|}{ Immunofluorescence nuclear pattern } \\
\hline Homogeneous & & + & & & & \\
\hline Speckled & & + & + & + & + & + \\
\hline Peripheral & & + & + & & & \\
\hline Nucleolar & & & + & + & & \\
\hline \multicolumn{7}{|c|}{ Specific nuclear antigens targeted in CTDs } \\
\hline dsDNA & & + & & & & \\
\hline ssDNA & & + & & & & \\
\hline Histones & & + & & & & \\
\hline $\mathrm{Sm}$ & & + & & & & \\
\hline U1-RNP & & + & $+(\mathrm{PH})$ & & & \\
\hline U3-RNP & & & $+(\mathrm{ILD}, \mathrm{PH})$ & & & \\
\hline U11-RNP & & & $+($ ILD $)$ & & & \\
\hline U12-RNP & & & $+(\mathrm{ILD})$ & & & \\
\hline rRNP & & + & & & & \\
\hline RNP & + & + & + & & & + \\
\hline SSA/Ro & & $+($ ILD) & & $+($ ILD) & + & \\
\hline SSB/La & & + & & & + & \\
\hline $\mathrm{Ku}$ & & + & + & $+(\mathrm{PH})$ & & \\
\hline Ki & & + & & & & \\
\hline Scl-70 & & & $+($ ILD) & & & \\
\hline CENP A-E & & & $+(\mathrm{PH})$ & & & \\
\hline Th/To & & & $+(\mathrm{ILD}, \mathrm{PH})$ & & & \\
\hline RNA-pol-1 & & & + & & & \\
\hline RNA-pol-2 & & & + & & & \\
\hline RNA-pol-3 & & & + & & & \\
\hline Jo-1 (cytoplasmic) & & & & $+($ ILD) & & \\
\hline EJ (cytoplasmic) & & & & $+($ ILD) & & \\
\hline OJ (cytoplasmic) & & & & $+(\mathrm{ILD})$ & & \\
\hline PL-7 (cytoplasmic) & & & & $+($ ILD $)$ & & \\
\hline PL-12 (cytoplasmic) & & & & $+($ ILD) & & \\
\hline KS (cytoplasmic) & & & & $+($ ILD) & & \\
\hline Zo (cytoplasmic) & & & & $+($ ILD $)$ & & \\
\hline YRS (cytoplasmic) & & & & $+($ ILD) & & \\
\hline Mi-2 (cytoplasmic) & & & & + & & \\
\hline SRP & & & & + & & \\
\hline CADM-140 (MDA5) & & & & $+(\mathrm{AIP})$ & & \\
\hline PM-Scl & & & + & + & & \\
\hline \multicolumn{7}{|c|}{ Non-ANA autoantibodies } \\
\hline RF & + & & & & & \\
\hline$\overline{\mathrm{ACPA}}$ & $+(\uparrow$ & & & & & \\
\hline
\end{tabular}

To establish the diagnosis there is no requirement for all listed autoantibodies to be present. + = Positivity in a variable percentage of patients $(1-100 \%)$. ACPA = Anticitrullinated peptide antibody; AIP = acute interstitial pneumonia; $\mathrm{ANA}=$ antinuclear autoantibodies; $\mathrm{ANCA}=$ antineutrophil cytoplasmic antibodies; CENP = centromere protein; dsDNA = double-stranded DNA; ILD = interstitial lung disease; IPF = idiopathic pulmonary fibrosis; MCTD = mixed CTD; $\mathrm{PH}=$ pulmonary hypertension; $\mathrm{DM}-\mathrm{PM}$ = dermatomyositis-polymyositis; $\mathrm{RA}=$ rheumatoid arthritis; $\mathrm{RF}=$ rheumatoid factor; $\mathrm{RNP}=$ ribonucleoprotein; $\mathrm{rRNP}$ = ribosomal ribonucleoprotein; $\mathrm{Sm}=$ Smith antigen; SRP = signal recognition particle; ssDNA = single-stranded DNA. 


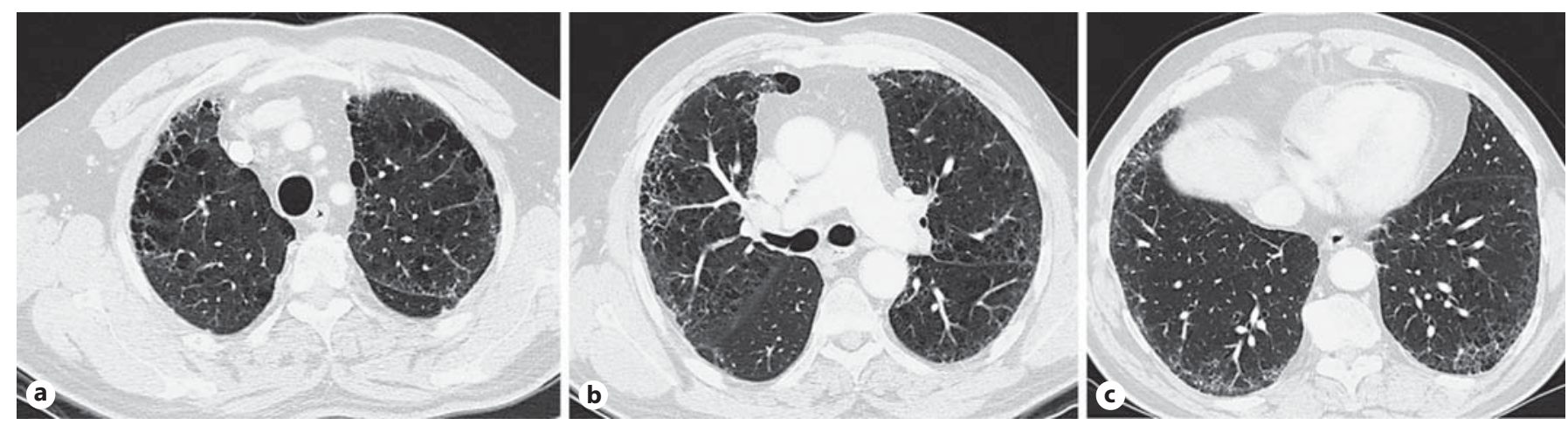

Fig. 1. HRCT showing emphysema changes in the upper lobes (a), emphysema and reticular interstitial pattern in the middle lung fields (b) and f-NSIP pattern in the periphery of the lower lobes (c). The patient is a middleaged male smoker with RA and combined PF and emphysema.

29]. UIP-type PF appears to affect more frequently aged, male smokers (male/female ratio $2 / 1$ ) $[25,30]$. The occurrence of UIP-type PF in RA is of paramount importance since in a similar manner with the idiopathic UIP in idiopathic PF does not respond to corticosteroids and immunosuppressants and presents an ominous prognosis [25, 31, 32]. In order to diagnose UIP-type PF in RA, surgical biopsy is not necessary and may be deleterious, since the recognition of the UIP pattern on high-resolution computed tomography (HRCT) is highly specific for the diagnosis in a patient with undisputable criteria for RA [33]. However, regarding the other ILDs involving the lungs in RA such as f-NSIP, desquamative interstitial pneumonia, a diffuse pattern of both chronic organizing pneumonia (COP) and chronic eosinophilic pneumonia (CEP), and lymphocytic interstitial pneumonia (LIP), a surgical, open or video-assisted thoracoscopic biopsy may become necessary to ensure diagnosis and target therapeutic decisions $[34,35]$. Indeed in the setting of $\mathrm{f}$-NSIP, in some patients histology may shift diagnosis and therapeutic decisions towards UIP-type PF [36]. Otherwise in confirmed f-NSIP cases, rheumatologists are used to administer corticosteroids and immunosuppressants or other agents, although there are no adequate international protocols proving their real effectiveness, and controversy remains [37, 38]. On the other hand in COP and CEP, corticosteroids constitute a secure choice assuring that tapering and low-dose corticosteroid maintenance may obviate toxicity and recurrence, respectively [39-41]. In the setting of desquamative interstitial pneumonia, considerable therapeutic uncertainty remains, especially in nonsmokers, though clinicians are prone to use corticosteroids $[42,43]$. Finally, LIP is both sensitive to corticosteroids and rituximab [44].
Combined PF and emphysema may also be observed in smokers with RA and adversely affects prognosis when complicated by the development of severe pulmonary hypertension [45] (fig. 1a-c).

\section{Pleural Disease}

Less than $5 \%$ of patients with RA may experience in life a pleural effusion, mainly aged males with subcutaneous rheumatoid nodules [27, 46, 47] (fig. 2a, b). Fever and pleuritic chest pain are observed less commonly than in lupus pleuritis, and a proportion of patients may present no pleuritic symptoms [48]. Pleural effusion in RA may present a prevalence of polymorphonuclear or mononuclear cells according to the acuteness of the process and characteristically presents (in chronicity) as an exudate with low glucose $(<40 \mathrm{mg} / \mathrm{dl})$, low $\mathrm{pH}(<7.20)$ and high lactate dehydrogenase levels ( $>700$ IU/l) [49]. The pleural levels of RF reflect those of the blood. Cytology may also be suggestive of the diagnosis when it fulfills the so-called Naylor criteria, e.g. (1) elongated macrophages, (2) round multinucleated macrophages and (3) background of granular necrotic debris [50]. Ragocytes, IgG and/or RF inclusions in multinucleated macrophages may be nonspecific [47]. If surgical biopsy becomes necessary, rheumatoid nodules may be observed at the level of the pleural surfaces (fig. 3). Rheumatoid pleuritis may resolve spontaneously or putatively improve with RA treatment [27, 46]. In some patients rheumatoid pleuritis may persist asymptomatic indefinitely, the pleural fluid may degenerate into pseudochylothorax (high cholesterol levels) while pleural surfaces become thickened [51] (fig. 4). Extensive pleural thickening may lead to trapped lung [52]. Occasionally in RA pleural effusion may be the result of necro- 

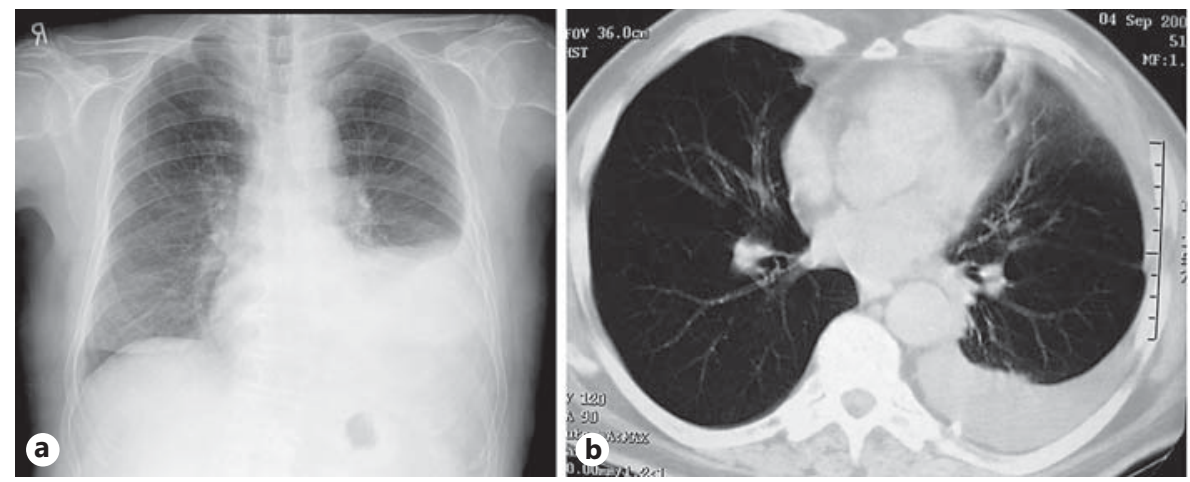

Fig. 2. Assessment of a 73-year-old male heavy smoker with arthralgias of the small hand joints of 7 years' duration treated only with nonsteroidal anti-inflammatory drugs. Morning stiffness, arthritis of the hand joints, cervical and thoracic spine pain, fatigue, anorexia and significant weight loss appeared during the last few weeks. Pleural fluid examination revealed a lymphocytic exudate with a $\mathrm{pH}$ of 7.14 , glucose $13 \mathrm{mg} / \mathrm{dl}$ and lactate dehydrogenase

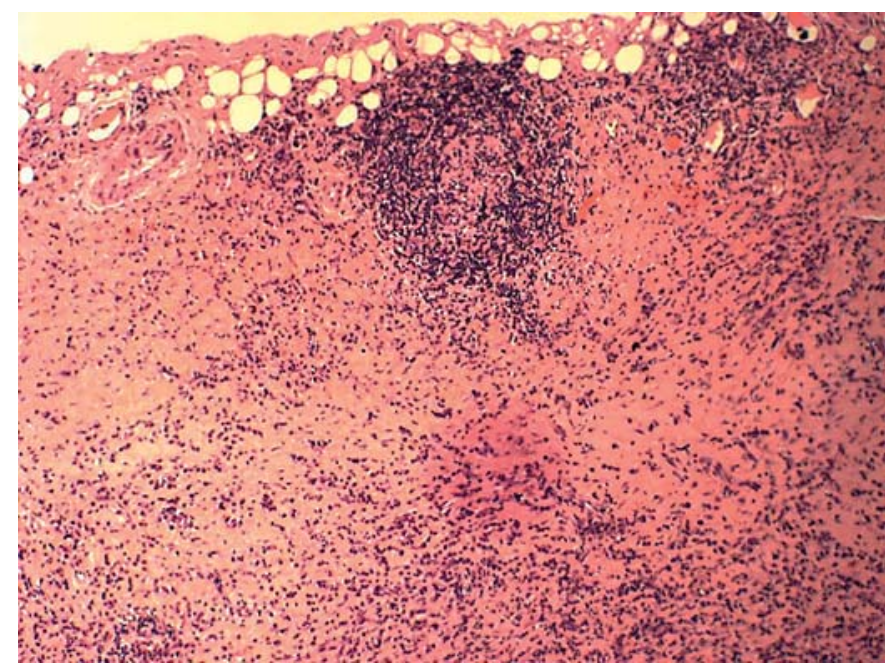

Fig. 3. Rheumatoid nodule. Surgical biopsy of the pleura of the same patient as in figure 2, revealing a granuloma lesion consisting of layers of palisaded epithelioid histiocytes around a focus of fibrinoid necrosis surrounded by chronic inflammatory cells and fibrosis.

sis of a peripheral rheumatoid nodule and the development of a bronchopleural fistula leading to empyema [53]. In such clinical circumstances pneumothorax may also ensue or even a pyopneumothorax [54].

\section{Airway Disease}

Bronchiolectasis-bronchiectasis is common in RA (around one third of the patients are involved) which also
2,141 IU/l. Cytology examination demonstrated histiocytes and a necrotic background material. Examination for tuberculosis and neoplastic disease was negative. Blood autoimmunity testing was positive for RF and anti-cyclic citrullinated peptide antibodies. a Chest radiograph showing a moderate left pleural effusion. b CT scan showing little change in quantity during several weeks' observation and clear lung fields.

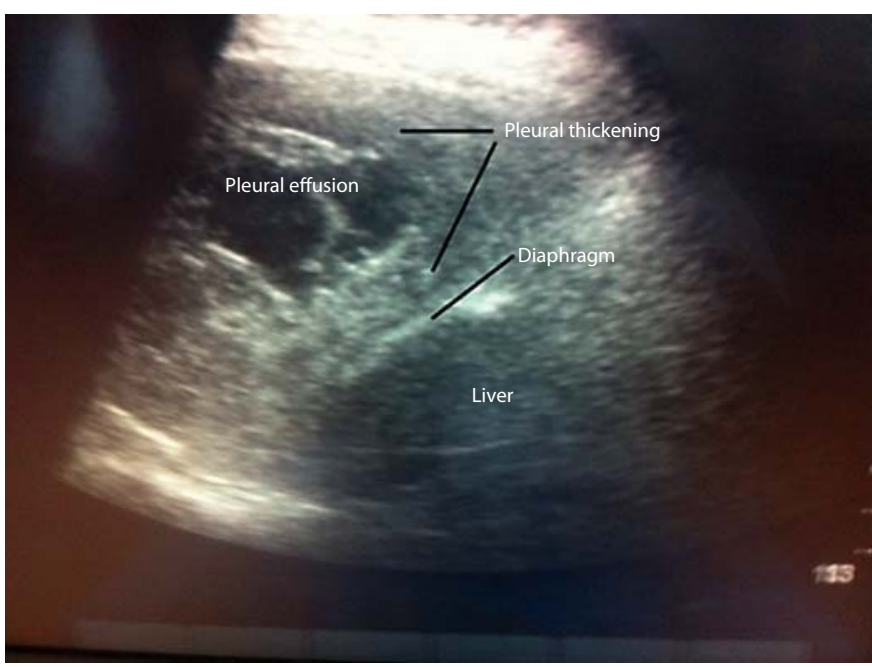

Fig. 4. Transthoracic ultrasound detecting multiloculated pleural fluid and extensive pleural thickening of the left hemithorax in a middle-aged male patient with long-lasting RA.

constitutes the CTD most commonly associated with significant airway disease [55] (see online suppl. fig. 2). The pathogenesis of bronchiectasis is unknown but several factors may concur such as: (a) genetic predisposition, (b) the commonly occurring factors in RA follicular bronchiolitis in the ambit of bronchus-associated lymphoid tissue (BALT) hyperplasia which concurs in small airway obstruction and denotes sustainable antigenic stimula- 
Fig. 5. Assessment of a middle-aged woman with long-standing RA and multiple rheumatoid nodules for the last 10 years. a Posteroanterior chest radiograph showing multiple bilateral lung nodes with cavitation. b-d HRCT scans showing cavitated and noncavitated lung nodules. Curiously the right upper lobe node presents a cuboid necrotic inclusion.

Fig. 6. a, b PET lung scans of the same patient as in figure 5 showing a medium-tohigh intensity signal of the lung nodules including those presenting cavitation despite their long-lasting presence.
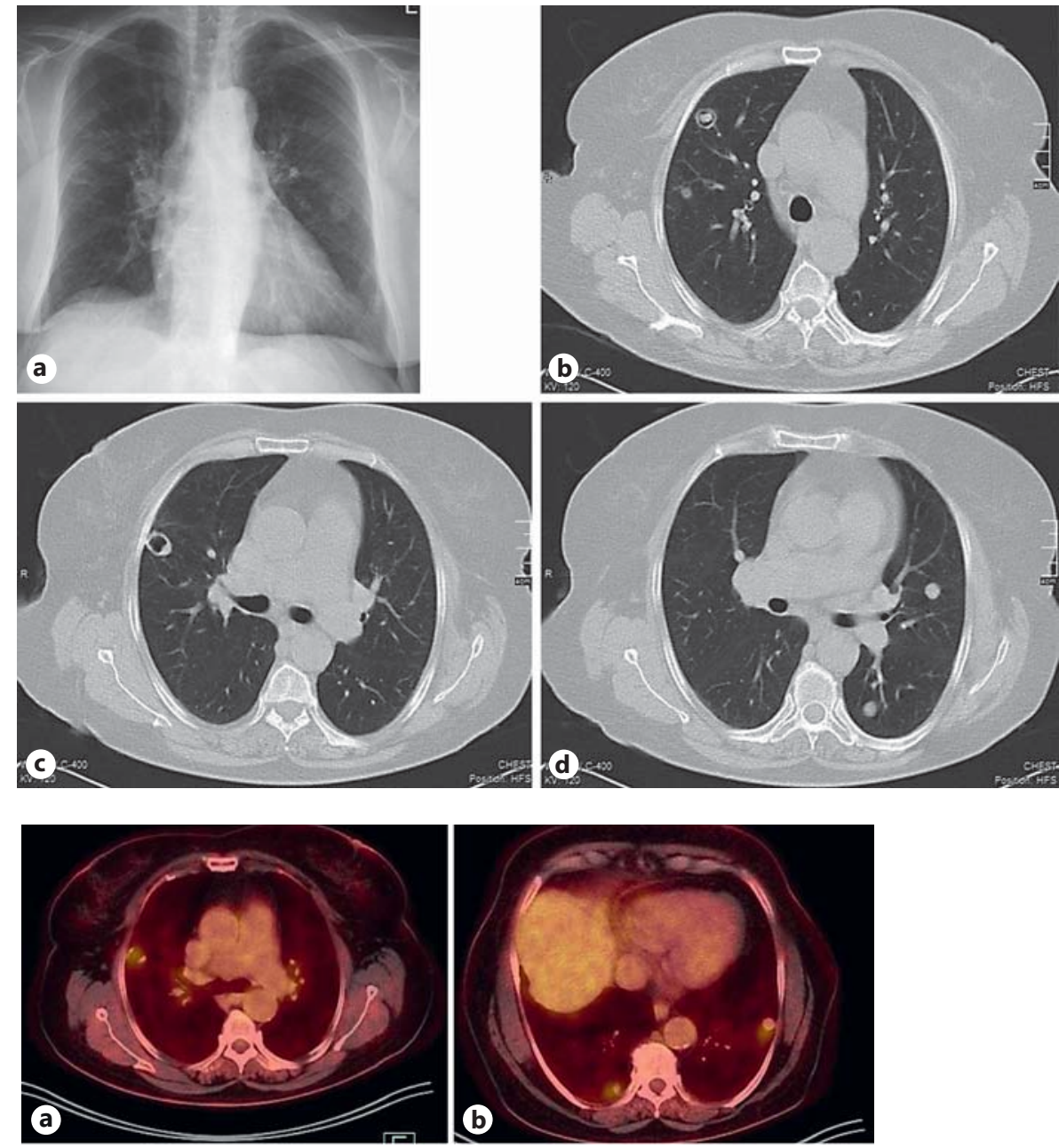

tion from unspecified antigens including microbes, (c) repetitive infections (see online fig. 3a, b), (d) diseasemodifying antirheumatic drugs ('lung microbial floramodifying drugs') and (e) others less clear [56]. The presence of bronchiectasis is almost always accompanied by colonization by microbes, and the development of multiantibiotic-resistant bacteria including atypical mycobacteria poses considerable therapeutic dilemmas since disease-modifying drugs (e.g. methotrexate), rituximab or biological factors (e.g. anti-tumor necrosis factor antibody therapies) predispose to severe lung infections [57]. Bronchiectasis adversely affects prognosis [58]. Bronchiolitis obliterans, a form of severe constrictive bronchiolitis, occurs rarely in young patients with RA and constitutes an untreatable condition leading to severe respiratory failure and premature death [59]. Rarely also the upper airways may be involved in RA under different forms such as rheumatoid nodules of the vocal cords, vasa

Lung Involvement in Rheumatologic Disease nervorum vasculitis of the recurrent laryngeal and/or vagus nerves, and cricoarytenoid arthritis [60]. Occasionally, emergency measures may become necessary to ensure the patency of the airways [61].

\section{Pulmonary Necrobiotic Nodules}

Pulmonary nodules constitute the most characteristic and specific lung manifestation of RA, occur rarely, may involve both lungs, and when solitary pose significant differentiation problems from malignancy [62, 63] (fig. 5ad). Histologically they consist of a fibrinoid necrosis center surrounded by palisading histiocytes peripherally circumscribed by plasma cells and lymphocytes [64]. Positron emission tomography may be positive even in long-standing nodules [65] (fig. 6a, b). Rheumatoid nodules may complicate the disease course, leading to hemoptysis or infection, and may rupture in the pleural space $[53,54]$. The fate of the nodules is variable since 


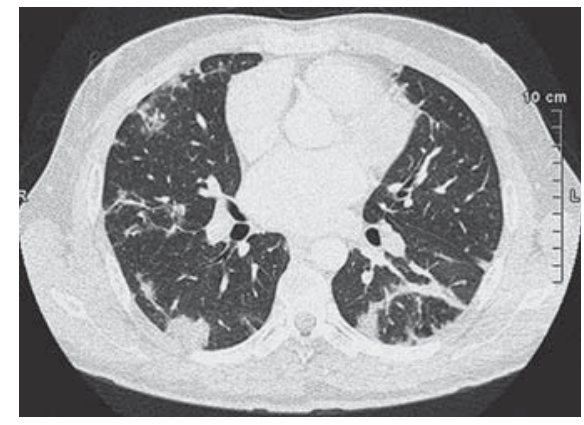

Fig. 7. HRCT of the chest depicting multiple, patchy, bilateral areas of consolidation with no interstitial septal thickening. The patient is a 28 -year-old male diagnosed with SLE (lupus nephritis) since the age of 5 , treated with azathioprine and prednisone, who presented with dyspnea and fever. A complete evaluation did not yield any microbial infection, and the dose of prednisone was increased presuming a diagnosis of COP.

they may persist, resolve or increase under treatment or spontaneously [62]. Caplan's syndrome occurs in association with pneumoconiosis where the nodules characteristically present an additional rim of dust deposition [66].

\section{Pulmonary Vascular Disease}

Secondary pulmonary hypertension may occur in any form of severe chronic lung manifestation in RA including venous thromboembolism that appears to occur more frequently in these patients $[67,68]$. The development of $\mathrm{PAH}$ has been described rarely and may severely affect prognosis [69]. Secondary amyloidosis and DAH have also been described in RA patients [70, 71]. Finally, other rarer lung manifestations in RA are shown in online supplementary table 1 [26].

\section{Systemic Lupus Erythematosus}

SLE is a systemic autoimmune inflammatory disorder mainly affecting women characterized by multiorgan involvement including the lungs and pleura and presenting in most patients anti-double-stranded DNA and antiSmith autoantibodies as well as several other anti-extractable nuclear antigen, anticytoplasm and anti-cellular membrane autoantibodies [72]. Direct autoantibodyand immune complex-mediated tissue damage is related to clinical expression $[73,74]$. Respiratory manifestations occur commonly in SLE, mainly infective pneumonias, pleural disease and pulmonary thromboembolism [75,
76] (see online suppl. table 2). Less common manifestations include pulmonary-renal syndrome presenting as acute pulmonary capillaritis or even bland pulmonary hemorrhage manifesting as DAH in association with rapidly progressive glomerulonephritis, different forms of ILDs, airway manifestations and diaphragmatic dysfunction called 'shrinking lungs with clear lung fields' [75] (see online suppl. table 2). 'Acute lupus pneumonitis' is a term commonly used by clinicians to define the 'lupus' patient who presents with fever and pulmonary infiltrates $[76,77]$. This term refers to nothing specific (probably a misnomer) since the differential diagnosis includes several acute respiratory conditions that occur in SLE such as infective pneumonia, pulmonary infarcts, DAH, COP or others, and a special effort should be made to assure diagnosis and target treatment $[78,79]$ (fig. 7). Patients with respiratory manifestations in SLE more appropriately represent the paradigmatic ones suffering from the previously reported 'vicious' combination of lung involvement, lung drug toxicity and infections related to the above two as well as to the 'mater' disease.

\section{Pulmonary Infections}

Pulmonary infections (bacterial, mycobacterial, viral and fungal) represent per se an SLE manifestation and not only a consequence of immunosuppression, and constitute a major determinant of morbidity and mortality in disease [80]. The so-called lupus 'paradox' relates to the fact that patients - though they present B lymphocyte hyperactivity, high levels of gammaglobulins including high antibody titers against viruses and other pathogens and a high ability to attack self-tissues - present severely impaired cellular and humoral immune responses to external offending agents, manifesting with recurrent infections including those of the lungs [81-83]. Preexisting lung damage, such as an ILD or airway disease, in addition to immunosuppression adds by altering the pattern of the pathogens (opportunistic microbes) and the severity of lung infections, adversely affecting prognosis [84, 85].

\section{Pleural Disease}

Pleural involvement is the other most paradigmatic respiratory manifestation in SLE [86]. It affects mainly women, may coexist with pericarditis and usually presents with pleuritic chest pain and fever far more frequently than rheumatoid pleuritis [87] (see online suppl. fig. $4 a-c)$. Lupus pleuritis may present bilaterally or involve one side, and on pleural fluid examination it represents an exudate with normal glucose and $\mathrm{pH}$ levels and a prev- 
alence of lymphomononuclear cells [88]. Pleural fluid ANA and lupus erythematosus cells add little to the diagnosis, and assessments are not recommended. Pleural biopsy is not a diagnostic option, and for its diagnosis it is necessary to rule out infection or embolism in the context of a patient fulfilling SLE criteria [88]. In some cases pleuritis and/or pleuropericarditis may ensue before the establishment of the diagnosis of lupus; in such cases the additional detection of early clinical clues and seroconversion for ANAs may guide diagnosis [89]. Lupus pleuritis responds fairly well to steroids [90]. Pharmacologic lupus may commonly present with pleuritis and in such cases discontinuing of the responsible drug (hydralazine, procainamide, isoniazid, phenytoin and chlorpromazine, the most definitely associated drugs) is sufficient to obtain remission [91]. Pleural inflammation with no evidence of pleural fluid may occur in lupus patients and presents with fever and pleuritic chest pain.

\section{Pulmonary Thromboembolism}

Pulmonary thromboembolism (PTE) is the third most characteristic respiratory manifestation in SLE patients appertaining to the spectrum of pulmonary manifestations of the lupus-associated antiphospholipid antibody syndrome (secondary) which also includes the chronic thromboembolic pulmonary hypertension, the catastrophic antiphospholipid syndrome and the less clearly lupus-antiphospholipid syndrome-associated PAH, DAH and acute respiratory distress syndrome [92-97]. The diagnosis of antiphospholipid syndrome requires the diagnosis of vascular thrombosis (arterial, venous, microvascular) and/or pregnancy morbidity in addition to the laboratory detection of lupus anticoagulant, anticardiolipin antibodies and anti- $\beta_{2}$-glycoprotein I antibodies [98]. One clinical and one laboratory criterion are enough for diagnosis [99]. Acute pulmonary embolism should always be ruled out in every patient with SLE presenting with dyspnea although PTE may be asymptomatic or present with sudden death [100] (see online suppl. fig. 5a, b). Anticoagulation treatment is as for any etiology of PTE [101]. Chronic thromboembolic pulmonary hypertension occurs in less than $5 \%$ of patients experiencing PTE, more commonly those presenting antiphospholipid antibodies [102]. Progressive dyspnea on exertion is the main clinical manifestation and when feasible pulmonary thromboendarterectomy is the treatment of choice [103]. Lupus-related PAH is most commonly occurring in patients presenting antiphospholipid antibodies and requires treatment as idiopathic PAH [104]. Catastrophic antiphospholipid syndrome occurs in less than $1 \%$ of pa-

Lung Involvement in Rheumatologic Disease tients with antiphospholipid syndrome and relates to multiorgan failure due to diffuse thrombotic microvessel occlusions [105]. It is usually precipitated by an infection, and the lungs may present acute respiratory distress syndrome related to several mechanisms including sepsis and microthrombosis [105]. Provision of excellent supportive care plus antibiotics, anticoagulants, plasma exchange and intravenous immunoglobulin administration for the most severe cases in addition to corticosteroids is the mainstay of treatment [94]. DAH is an uncommon pulmonary manifestation in SLE but bears an ominous prognosis [106]. DAH occurs mainly in the setting of a pulmonaryrenal syndrome and requires high-dose corticosteroids plus immunosuppressants to obtain remission [107].

\section{Interstitial Lung Disease}

Interstitial pneumonias of the type of the several histopathological and clinical diseases with the idiopathic ILDs are uncommon in SLE patients and occur mainly in overlap autoimmune syndromes [108]. UIP-type PF, $\mathrm{f}-\mathrm{NSIP}, \mathrm{COP}$ and LIP have been described and may require different therapeutic options; COP responds to steroids and LIP to steroids and/or rituximab $[75,109]$. UIPtype PF and f-NSIP are insensitive to steroids and immunosuppressants although both are commonly administered [110].

\section{Shrinking Lung Syndrome}

Shrinking lung syndrome defines the lupus patient with worsening dyspnea, diaphragmatic elevations and clear lung fields [111] (fig. 8). Extensive functional evaluation shows a restrictive pattern in spirometry, a decreased DLCO with normal KCO, decreased maximal expiratory and inspiratory pressures, absence of pulmonary hypertension, a normal ventilation/perfusion lung scanning and the absence of pleural and parenchymal disease in CT. Diaphragmatic inflammatory myositis and/or phrenic neuropathy may represent the underlying etiology [112]. The administration of corticosteroids and immunosuppressants constitutes an effective therapeutic option [113]. Other less common lung lupus manifestations are reported in the online supplementary table $2[48$, $75,106,114-131]$.

\section{Systemic Sclerosis}

SS, 'scleroderma', is an autoimmune rheumatic disorder characterized by skin (derma) sclerosis, small vessel hyperreactivity (vasoconstriction) mainly but not exclu- 
sively manifesting with Raynaud's phenomenon, renal crisis and $\mathrm{PAH}$, visceral organ involvement and several ANAs and extractable nuclear antigen seropositivities $[132,133]$ (table 1). Limited cutaneous SS affects mainly the skin of the face and the forearms plus internal organs, among them the esophagus and the lungs [134] (see online suppl. table 3). In this latter clinical setting in case of positive anticentromere autoantibodies scleroderma-related PAH may ensue and adversely affects prognosis [135]. Diffuse cutaneous scleroderma additionally affects the skin of the chest and abdominal wall plus internal organs, mainly the lungs. Lung involvement presents commonly anti-Scl-70 autoantibodies and manifests as an ILD, f-NSIP-type fibrosis and less commonly as UIP-type PF [136].

\section{Interstitial Lung Disease}

A patient with diffuse cutaneous SS without any type of diffuse fibrotic ILD is uncommonly encountered [137]. Fibrotic ILD is also evident in a considerable proportion of patients with limited cutaneous SS [138]. The best means for its diagnosis is the performance of a low-dose HRCT without iodinated contrast $[139,140]$. The pattern is more frequently the one of f-NSIP, e.g. bilateral peripheral lower lobe ground-glass infiltrates in addition to traction bronchiolectasis-bronchiectasis plus a fine reticular pattern [141, 142]. In some patients an early peripheral honeycomb pattern may be observed defining the UIP pattern [143]. At any case gradually ground-glass opacities become reticular and finally leave the place in the honeycomb. This may take several years [143]. In smokers, combined pulmonary fibrosis and emphysema may also ensue (see online suppl. fig. 6a-c). However, irrespective of the imaging pattern on HRCT, progression and prognosis of disease depend mainly on the severity of the already established functional deterioration [144, 145]. Pulmonary function tests in these patients usually show a restrictive pattern with low lung diffusion capacity and exercise oxygen desaturation, though exercise tests are not usually performed in scleroderma patients due to low performance in lower arm mobility [146, 147]. On chest auscultation 'Velcro sounds' are commonly audible [148]. On clinical examination digital clubbing is absent in scleroderma patients with the exception of the occasional patient with 'scleroderma sine scleroderma' and lung fibrosis [149]. Pseudo-clubbing may be observed in scleroderma patients, which defines deformities of the distal phalanges due to bone resorption in relation to repetitive ischemic episodes of the distal digits in patients with severe Raynaud's phenomenon [150]. Regard-

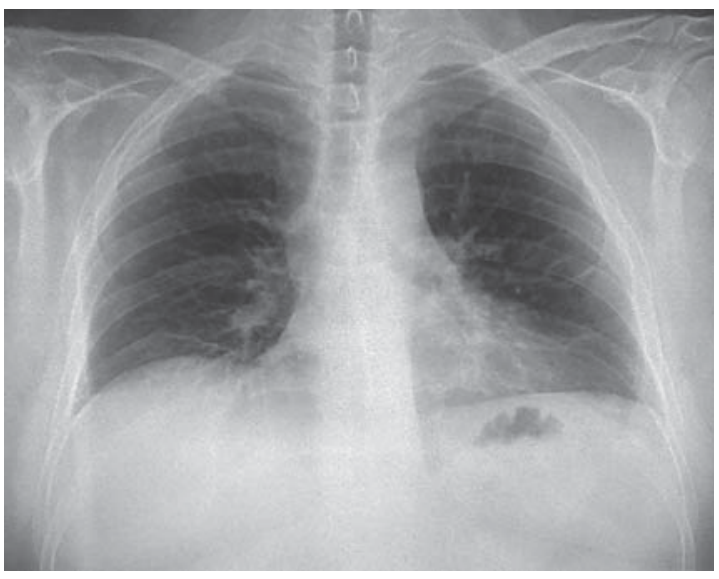

Fig. 8. The same patient as in figure 7. A few months later the consolidations and the fever had completely resolved while the dyspnea persisted. As shown in the radiograph, both hemidiaphragms are elevated and no parenchymal abnormalities are evident, findings compatible with the diagnosis of shrinking lung syndrome. Upon dose de-escalation, lung infiltrates reappeared and surgical biopsy confirmed COP and additional UIP changes. A flareup of the 'mater' disease with renal, cardiac, joint and bone marrow involvement led his physician to administer cyclophosphamide pulses. A few days later, the patient developed febrile neutropenia and septic shock due to Neisseria meningitidis and expired while intubated in the intensive care unit.

ing the therapeutic options, rheumatologists are used to treat fibrotic ILDs with immunosuppressants despite poor evidence of benefit [151].

\section{Pulmonary Arterial Hypertension}

$\mathrm{PAH}$ is encountered in $7-12 \%$ of scleroderma patients, and based on the most recent updated clinical classification of pulmonary hypertension it is mainly of the group $1 \mathrm{PAH}$ type similar to idiopathic $\mathrm{PAH}$, although pulmonary hypertension due to left heart disease (group 2) and due to ILD and hypoxemia (group 3) may also develop either alone or in combination $[148,152]$ (see online suppl. fig. 7a-d). As already stated, PAH severely influences survival since less than half of patients with scleroderma-related $\mathrm{PAH}$ are still alive 3 years after its diagnosis. In comparison with idiopathic $\mathrm{PAH}$, patients with scleroderma-related PAH have a threefold increased risk of death [135, 153]. Dyspnea, fatigue and palpitations which are the most common symptoms of pulmonary hypertension are often underestimated or/and are frequently attributed to heart and lung comorbidities leading to a significant delay of the diagnosis unless the patient is regularly screened or develops more alarming and specific 
pulmonary hypertension symptoms such as syncope, orthostasis or chest pain [135]. Due to the high prevalence of PAH in SS and the major impact on quality of life and survival, all patients with SS should regularly undergo evaluation for early detection of PAH in referral pulmonary hypertension centers initially with clinical evaluation, transthoracic echocardiography and pulmonary function testing. In high-risk SS patients, that is those with abnormal echocardiography findings, decreased DLCO without coexistent ILD and rapidly deteriorating DLCO and dyspnea, PAH should be documented with right heart catheterization $[154,155]$. Although any scleroderma patient may develop PAH, those older at diagnosis, with severe Raynaud's phenomenon, a diagnosis of limited cutaneous SS and a specific autoantibody profile with positivity for anti-U3 ribonucleoprotein antibodies, anti-topoisomerase-IIa antibodies and/or anticentromere antibodies are considered to be at higher risk [156]. Pathogenetically PAH in scleroderma is attributed to inflammation, endothelial dysfunction and remodeling of small-to-medium size pulmonary vessels in a milieu of characteristic autoimmune dysregulation and genetic predisposition [157]. Regarding treatment, all three categories of drugs used for idiopathic PAH (prostacyclin analogs, endothelin receptor antagonists, and phosphodiesterase inhibitors alone or in combination) are also indicated for SS-PAH patients without so far any proved survival benefit [104]. Aggressive immunosuppression considered of some benefit in other autoimmune diseaserelated pulmonary hypertension such as SLE- and MCTDrelated pulmonary hypertension has not been found to be effective in SS-PAH although the role of new immunomodulatory agents is under investigation $[158,159]$. One of the most challenging areas in managing SS-PAH patients is the timely diagnosis of the disease and the selection of those patients with diffuse cutaneous SS who develop 'disproportionally' high mean pulmonary artery pressure values, implying beyond a causative relation to the existing ILD an intrinsic vascular process that could potentially respond to PAH specific treatment $[160,161]$. Lung and/or heart transplantation remains the last option in carefully selected SS-PAH patients [162].

\section{SS and Lung Cancer}

Scleroderma (diffuse, limited and overlap) is associated with an increased risk of lung cancer [163-168]. The majority of patients with scleroderma who develop lung cancer have underlying interstitial lung fibrosis, are female and the most frequent tumors are adenocarcinoma or of the bronchioloalveolar cell type [169], not necessar-

Lung Involvement in Rheumatologic Disease ily associated with cigarette smoking [163]. The average interval time between the onset of these two diseases appears to be more than 5 years [163, 170-172]. It is believed that the chronic inflammation and repair that occur in SS-ILD results in recurrent cellular injury and genetic damage to local epithelial cells, predisposing to the development of cancer through sequential cellular morphological alterations [173]. Such an association is further supported by the observation that idiopathic lung fibrosis also appears to be linked to lung cancer [174]. In addition, the frequent use of immunosuppressive drugs, such as cyclophosphamide, may predispose to the development of lung cancer independently of the influence of underlying disease $[175,176]$.

\section{Dermatomyositis-Polymyositis}

Dermatomyositis-polymyositis (DM-PM) along with necrotizing autoimmune, inclusion body and overlap myositis constitute the idiopathic inflammatory myopathies [177]. DM and PM are rare disorders with an annual incidence of less than 10 per million population and are both characterized by proximal muscle weakness, elevated serum muscle enzymes, electromyographic features of myopathy, inflammatory cell infiltrates in muscle tissue and myositis-specific autoantibodies [177]. In addition DM presents characteristic cutaneous manifestations such as Gottron papules, heliotropic rash and mechanic's hands. Both conditions may overlap with other CTDs or present in the setting of malignancies (cancerassociated DM-PM). In every patient with a diagnosis of DM-PM, PET should be obligatory in order to detect or exclude malignancy [177]. Lung manifestations occur commonly in DM-PM, the most common of the extramuscular manifestations of the disease; they have been reported in up to $75 \%$ of patients and constitute a major determinant of morbidity and mortality $[178,179]$ (see online suppl. table 4 ). In approximately $20 \%$ of cases pulmonary involvement precedes the diagnosis of DM-PM [179].

The pulmonary involvement in DM-PM consists mainly in the form of ILD more frequently f-NSIP, followed by UIP and COP [180] (see online suppl. fig. 8a-c). Rare cases of LIP, acute fibrinous and organizing pneumonia, DAH and CEP have all been described [181-184]. Pneumomediastinum has also been reported [185] (fig. 9a, b). Among the above lung manifestations several myositis-specific autoantibodies appear to correspond, the identification of which has changed our understand- 


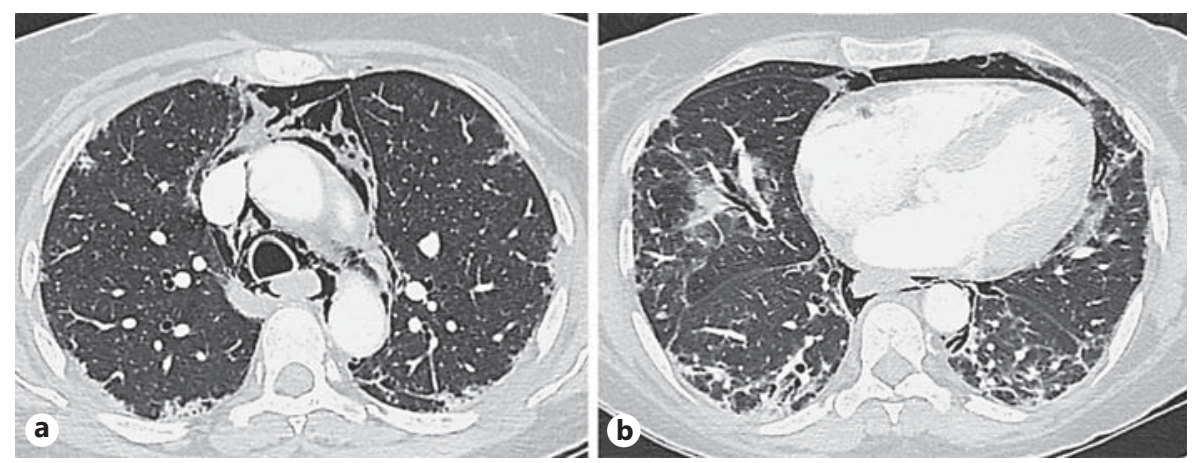

Fig. 9. a, b CT of the chest demonstrating pneumomediastinum on a background of subpleural reticulation, traction bronchiectasis and ground glass opacities of a 59-year-old nonsmoker female patient who presented at the emergency room complaining of acute chest pain and dyspnea on exertion. The patient had been diagnosed with clinically amyopathic dermatomyositis with ILD lung involvement 1 year previously. Autoimmunity testing showed positivity for anti-melanoma differentiation-associated protein 5 antibodies. The patient was treated with immunosuppressants (corticosteroids with rituximab followed by cyclophosphamide) with partial improvement. ing of the natural history of DM-PM (table 1) [186]. The most typical phenotype is the antisynthetase syndrome, i.e. the coexistence of autoantibodies to aminoacyl-tRNA synthetases, highly specific for myositis, and one or more of the following clinical features: ILD, inflammatory myopathy, arthritis or arthralgias, Raynaud's phenomenon, mechanic's hands and fever. Although there are 20 different aminoacyl-tRNA synthetases for a single amino acid, only in 8 of them has an antibody been identified so far, with the most common being the anti-histidyl antibody (Jo-1) which is encountered in $20-30 \%$ of DM-PM patients. The anti-threonyl (PL-7), anti-alanyl (PL-12), anti-glycyl (EJ) and anti-isoleucyl (OJ) antibodies are encountered in less than 5\% and the anti-asparaginyl (KS), anti-phenylalanyl (Zo) and anti-tyrosyl (YRS) antibodies in less than $1 \%$ of DM-PM patients. Overall, ILD in antisynthetase syndrome is present in nearly $90 \%$ of cases, reaching even $100 \%$ in cases of anti-PL-7, anti-OK, antiEJ or anti-Zo positivity [186]. Thorough screening for anti-tRNA synthetase autoantibodies can unmask cases of antisynthetase syndrome falsely diagnosed as idiopathic' ILDs [186, 187]. The clinical implication of distinguishing these conditions is related to the worse prognosis of truly idiopathic fibrotic ILDs especially the UIPtype PF. Overall, antisynthetase syndrome shows a predominance of the f-NSIP ILD pattern, and the response to treatment is reported to be more favorable compared to nonantisynthetase syndrome ILD DM-PM patients [188]. On the other hand, the presence of a UIP pattern on HRCT and of DLCO lower than $45 \%$ is associated with deteriorating ILD even in the ambit of antisyn- thetase syndrome, while the coexistence of anti-Jo- 1 with anti-SSA/Ro antibodies characterizes also a subgroup of antisynthetase syndrome patients with severe and treatment unresponsive ILD [189, 190].

Clinically amyopathic dermatomyositis (CADM) is a DM subtype that shares the same characteristics as DM, i.e the characteristic cutaneous manifestations, while the muscle involvement is minimal or absent. CADM is complicated by ILD in up to $75 \%$ of patients and is associated with a poor prognosis especially in the cases complicated by a rapidly deteriorating ILD allowing a 6-month survival only in $40 \%$ of patients [191, 192]. This pattern of rapidly deteriorating ILD may in some patients be the first manifestation of lung involvement in DM and may present as acute interstitial pneumonia, that is the development of diffuse alveolar damage upon normal (acute interstitial pneumonia) lungs or as an acute worsening in a background of abnormal fibrotic lungs (an already established fibrotic ILD) in the same manner as the socalled acute exacerbations in idiopathic PF. Extensive radiologic abnormalities and high serum ferritin levels portend a poor prognosis in this subset of patients with CADM [193]. This pattern of a rapidly deteriorating ILD in the setting of CADM is usually associated with the presence of an autoantibody against melanoma differentiation-associated protein 5 (MDA5), also called antiCADM-140 autoantibody. The anti-melanoma differentiation-associated protein 5 antibody is present in 12$35 \%$ of DM patients, and in half of CADM patients, and is associated with a rapidly deteriorating ILD and bears a poor prognosis [194]. 
Among the different serum biomarkers investigated, high levels of tumor necrosis factor- $\alpha$ are associated with the development of ILD whereas those of IL-8 may predict a worse prognosis in the presence of ILD associated with DM-PM [195]. Furthermore, high levels of serum ferritin, IL-6, IL-8 and IL-10 characterize a more severe ILD phenotype in DM-PM [196]. Secondary lung complications include the development of pulmonary hypertension in the setting of already established ILD and complications related to the development of muscle weakness such as aspiration pneumonia and hypercapnic respiratory failure. Finally DM-PM can be complicated by many cancers, including bronchogenic carcinoma $[168,176]$.

The treatment in DM-PM consists of the administration of relatively high-dose corticosteroids and/or immunosuppressants (cyclophosphamide, azathioprine, mycophenolate mofetil, calcineurin inhibitors, infliximab, rituximab, intravenous immunoglobulin) that may positively or adversely affect the clinical course and prognosis of the coexpressed lung manifestation of the disease depending on the histopathologic pattern as already described. Due to the rarity of the inflammatory myopathies, high-quality studies regarding the treatment of the several forms of lung manifestation are lacking. The COP, CEP, LIP and acute fibrinous and organizing pneumonia patterns almost always respond favorably. The f-NSIP pattern of ILD is not clear if it responds to the treatment mentioned above or presents a slow progression on its own. The UIP-type PF and the development of diffuse alveolar damage constitute a phenotype nonresponsive to immunosuppression. In general the development of acute/subacute forms of lung disease, older age, low forced vital capacity and CADM diagnosis predict poor outcome in PM-DM-associated ILD [197].

\section{Primary Sjögren's Syndrome}

pSs, a slowly progressive autoimmune exocrine epithelitis, is characterized by both autoantibody production, such as those against the $\mathrm{Ro}(\mathrm{SSA})$ and $\mathrm{La}(\mathrm{SSB})$ ribonucleoproteins and RF, and lymphocytic infiltration of the exocrine glands, mainly the ocular and salivary ones, leading to diminished glandular secretions, e.g. 'xerophthalmia', dry eyes, and 'xerostomia', dry mouth, nominated years ago 'sicca syndrome' $[198,199]$. Several if not all exocrine tissues and organs of an exocrine apparatus are involved in pSs as well as several extraglandular sites [198]. In this latter case, immune-complex deposition or clonal transformation may play a role [198,

Lung Involvement in Rheumatologic Disease
199]. Sjögren's syndrome affects $0.5-1 \%$ of the general population, mainly middle-aged females (female/male ratio 10/1) [198]. Pathogenetically it is postulated that glandular epithelial cells in pSs become immunologically active cells by the incorporation of viral or other unknown antigens, express major histocompatibility complex class 1 and 2 molecules and costimulatory molecules B7 and produce cytokines and chemokines attracting locally both $\mathrm{T}$ helper and $\mathrm{B}$ lymphocytes rapidly transforming into antibody- and autoantibody-producing plasma cells [200, 201]. The inflammatory infiltrate described above may become severe enough to sovereign structure and function of the exocrine glands. B lymphocyte hyperactivity may also lead to several lymphoproliferative manifestations including lymphoma development in 2-5\% of patients [202-204]. Sjögren's syndrome may occur alone, as pSs or as secondary in association with another CTD, mainly RA and SLE nonobeying temporal rules [198].

It was Henrik Sjögren [205] who first recognized lung involvement in $\mathrm{pSs}$, describing features similar to the salivary and lacrimal lymphocytic infiltrations at the level of the submucosal tracheobronchial exocrine glands. Since then several studies have been interested in the lungs and described that in pSs multiple manifestations may occur though their prevalence is influenced by the methodology of investigation applied [206] (see online suppl. table 5). Furthermore, since Sjögren's syndrome may also occur in association with another CTD in up to $30 \%$ of patients, the co-occurrence of the second rheumatic disorder may influence the pattern of lung manifestation [207, 208]. For the above reasons discrepancies in the available literature persist concerning the pattern, the frequency and the clinical significance of lung involvement in pSs [207, 208]. In pSs the most commonly occurring lung manifestations include (1) tracheobronchial and bronchiolar disease, (2) a spectrum of lymphoproliferative manifestations including LIP and B-cell non-Hodgkin's lymphoma and (3) other interstitial pneumonias [206].

\section{Airway Manifestations}

'Rhina sicca', 'xerostomia' and 'xerotrachea' are terms referring to the dryness of the upper airways including the trachea due to the exhaustion of the resident exocrine secretory apparatus specific to the disease $[209,210]$. In addition a lymphocytic infiltrate of the bronchial airway mucosa beneath the lamina propria has been described and might be defined appropriately as 'lymphocytic bronchitis' more or less clinically expressed as 'xerobronchitis' [211]. Independently of the semantics 'sicca cough' is the 

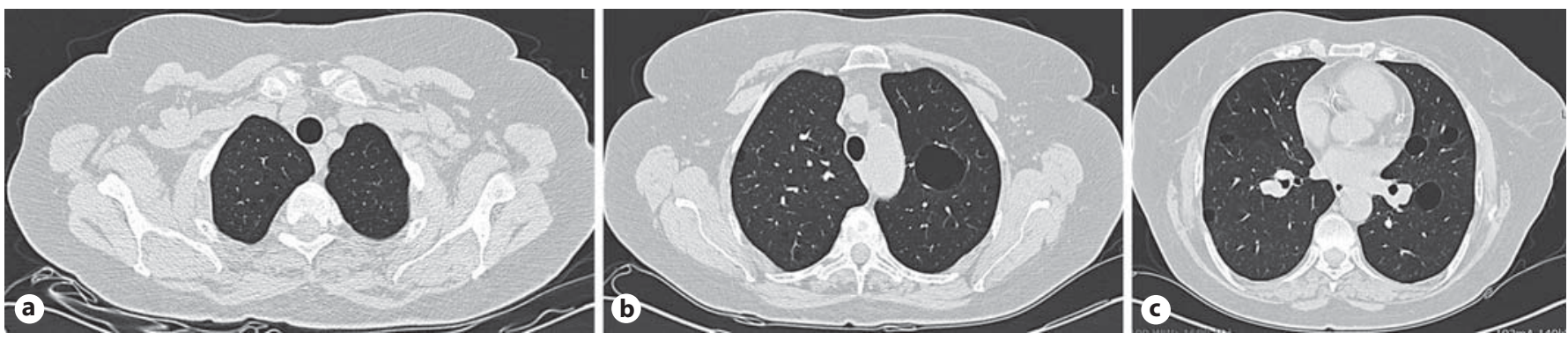

Fig. 10. a-c HRCT of the chest showing multiple discrete lung bullae (cysts) from the apex to basal segments interspersed in normal lung fields. Curiously, though pleural pressure and its alveolar counterpart are more negative in the upper lung segments, bullae increase in size from the apex to the base of the lung. The patient

main clinical manifestation beyond 'xerophthalmia' and 'xerostomia' in $\mathrm{pSs}$ patients occurring in more than $50 \%$ of patients $[209,210]$ and may also relate to a similar lymphocytic infiltrate through the small airways, e.g. lymphocytic bronchiolitis [212]. Due to the persistence of the unknown antigenic stimulation, hyperplasia of the BALT may appear and add to the airway manifestations by a variable, usually mild, degree of small airway obstruction. Indeed the most frequent physiological manifestation in patients with pSs is mild small airway obstruction not severe enough to create symptoms [213]. BALT hyperplasia may also be associated with the occasional formation of a limited number of bullae (fig. 10a-c). Severe bronchiolitis and bullous destruction of a considerable part of the pulmonary parenchyma are rare but clearly described [212] (fig. 11a-f).

\section{Lymphoproliferative Manifestations}

Airway manifestations in pSs are not per se disease expressions but probably part of an evolving process through several lymphoproliferative disorders from peribronchiolar BALT hyperplasia (follicular bronchiolitis) towards diffuse alveolar interstitial LIP characterized by the alveolar tissue infiltration of a polyclonal population of B lymphocytes and finally to the emergence of a monoclonal B lymphocytic population such as in the development of a marginal zone B-cell non-Hodgkin's lymphoma or other more aggressive lymphomas [204] (fig. 12a-d).

\section{Other Interstitial Pneumonias}

More recent studies in selected patients with Sjögren's syndrome using surgical biopsies have also described a number of ILDs such as f-NSIP (the most frequently occurring), cellular NSIP, UIP, COP and lung amyloidosis is a middle-aged woman with long-standing pSs with 'sicca cough' and absolutely normal spirometry. Bulla formation might relate to bronchiolar obstruction and valve mechanism from the development of BALT hyperplasia. There are no reasons to perform any lung biopsy. in addition to the already described LIP [214-216]. However, this is not part of our clinical experience in very wellselected pSs patients, especially the development of fibrotic ILDs, raising thoughts about the coexistence of a second CTD although not yet fulfilling undisputed diagnostic criteria [29].

\section{Mixed Connective Tissue Disease}

MCTD is an overlapping CTD sharing clinical features with SLE, PM-DM, RA and SS characterized by positive anti-U1-ribonucleoprotein autoantibodies indispensable for diagnosis [217]. The most commonly occurring systemic manifestations are Raynaud's phenomenon, 'puffy hands', arthralgia-arthritis, myositis and sclerodactyly [217]. Two or three of the above plus anti-U1-ribonucleoprotein autoantibodies are necessary for diagnosis [218]. Pulmonary manifestations in MCTD are common and pleomorphic in relation to the multinosologic provenience $[45,219-222]$ (see online suppl. table 6). Among them the most commonly occurring are f-NSIP (see online suppl. fig. 9a-c), serositis and PAH [223]. The clinical picture and the therapeutic considerations for the above lung manifestations have already been described although some investigators report a more benign course regarding PAH and f-NSIP in MCTD [224, 225].

\section{Ankylosing Spondylitis}

Ankylosing spondylitis is a chronic inflammatory disorder mainly affecting the axial skeleton, e.g. spine (costovertebral and apophyseal joints) and sacroiliac joints of 

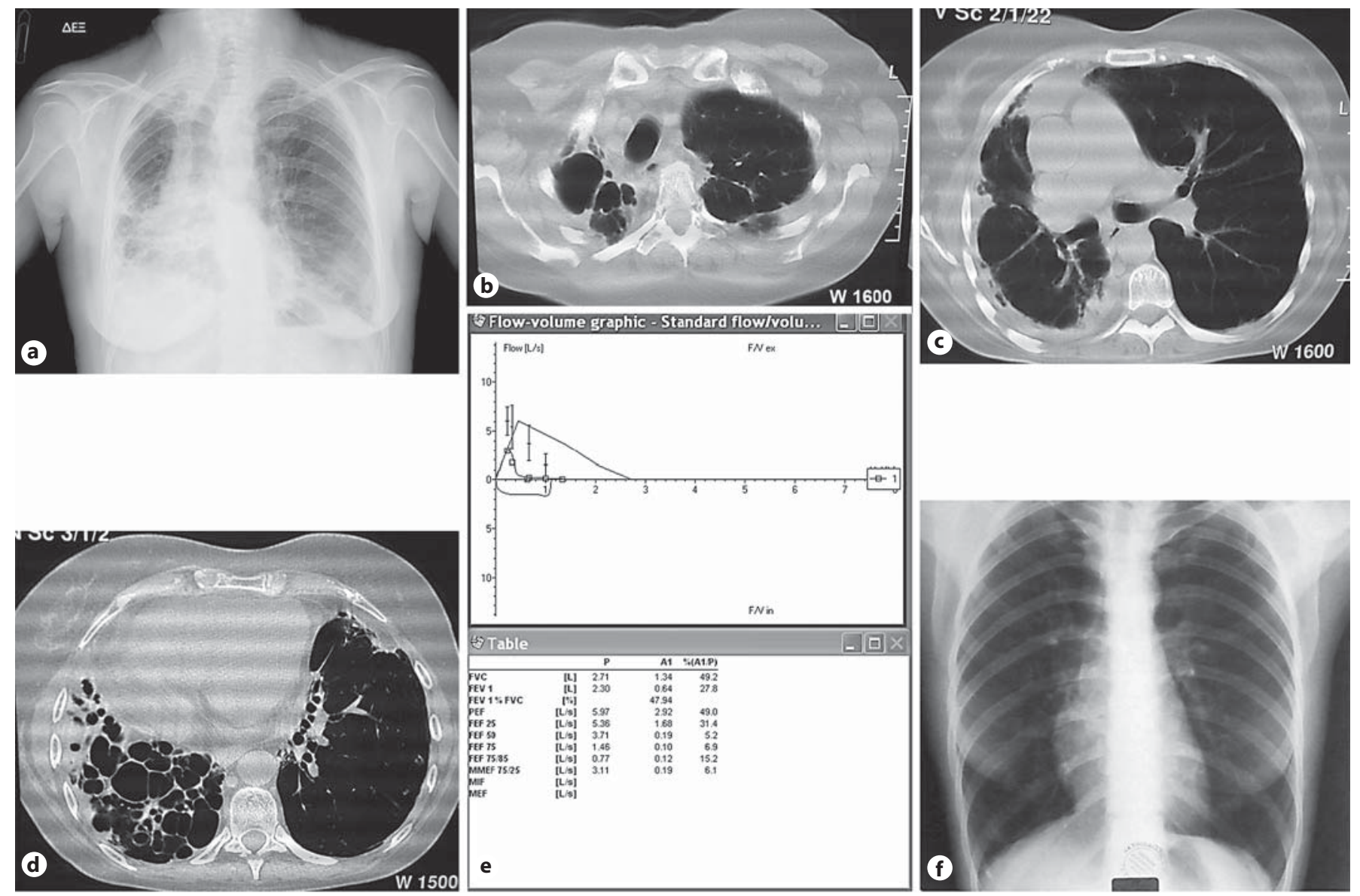

Fig. 11. This posteroanterior chest radiograph (a) shows the fibrobullous transformation of the right lung also shown in the CT scans at 3 different levels (b-d) disclosing also cystic spaces at the left lung base. e The flow-volume curve shows severe obstruction. The patient is a middle-aged woman with long-standing pSs (more than 30 years) complaining of severe dyspnea on exertion. $f$ A chest radiograph of 30 years ago shows only hyperinflation. The above findings might relate to severe bronchiolitis obliterans with a curious asymmetric distribution. the pelvis. In progressive disease complete fusion and rigidity of the spine occurs, severely affecting its mobility [226]. Occasionally, peripheral joints may be involved as well as extra-articular sites such as the lungs or others [227-229]. Ankylosing spondylitis is a classic RA-seronegative spondyloarthropathy and affects $0.1 \%$ of the population. Men are far more frequently affected than women (16:1) and more than $90 \%$ of Caucasians with the disease possess the HLA-B27 antigen [230]. Respiratory manifestations (table 2) in ankylosing spondylitis are not uncommon and affect mainly the thoracic cage, the lungs in the form of an apical fibrobullous disease and obstructive sleep apnea syndrome (OSAS) [231-246] (see online suppl. table 7).

Lung Involvement in Rheumatologic Disease

\section{Thoracic Cage Involvement}

The additional involvement of the sternoclavicular joints and enthesitis (inflammation of the ligaments) of the manubriosternal symphysis may add to thoracic cage dysmobility [247]. Ribcage expansion is reduced but the abdominal expansion is preserved [248] as well as the diaphragmatic movement avoiding hypercapnic 'ventilator pump' failure [232].

\section{Lung Manifestations}

Apical fibrobullous disease is the most characteristic manifestation in ankylosing spondylitis and affects mostly HLA-B27-positive males [235] (fig. 13a-f). Its pathogenesis is unknown, and concurrence of several factors has been advanced such as disordered ventilation and/or 
Fig. 12. Assessment of a middle-aged woman with long-standing pSs who developed moderate dyspnea on exertion. a This posteroanterior chest radiograph shows diffuse bilateral infiltrates with perihilar distribution more prevalent in the middle and lower lung fields with several interspersed lung cysts. b-d HRCT at 3 different levels showing a combination of alveolar peribronchial and peribronchiolar infiltrates with their corresponding broncho-bronchiolograms, multiple lung bullae more prominent at the middle and basal segments, and a diffuse 'tree in bud' pattern. The above findings were suggestive of an LIP, and a surgical biopsy was proposed to the patient but she refused. Five years later, because of progressive deterioration of dyspnea, she accepted surgical biopsy disclosing the development of low-grade marginal zone B-cell lymphoma.
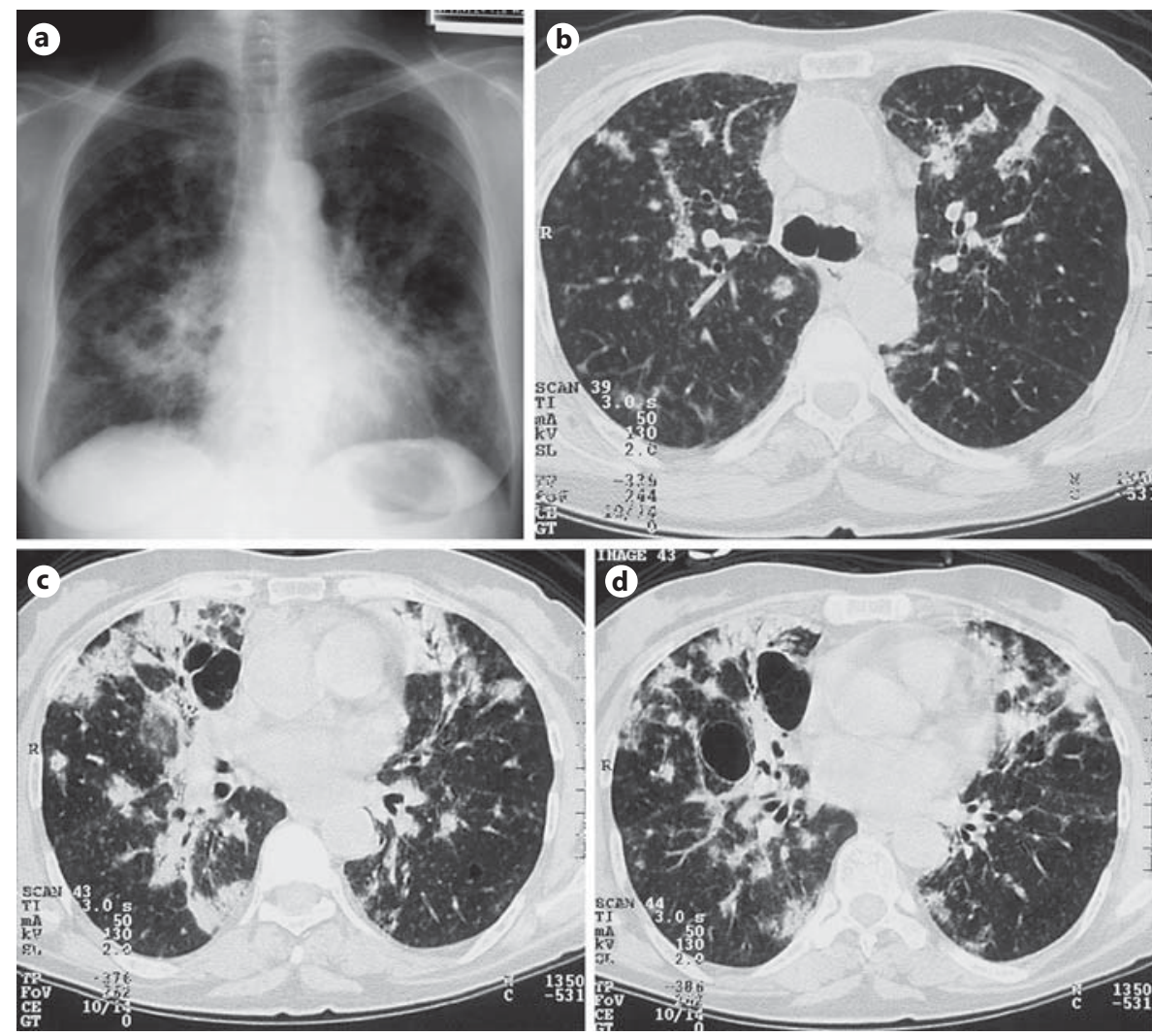
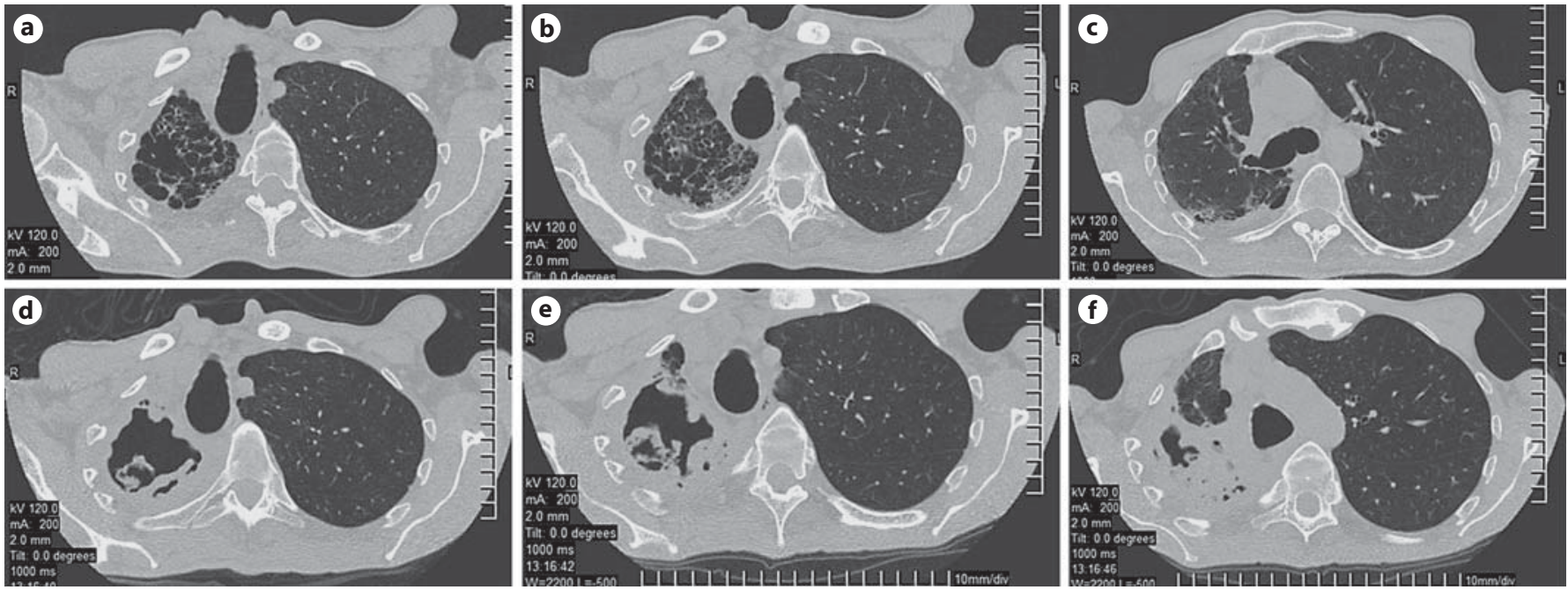

Fig. 13. Assessment of a 52-year-old man, never-smoker, with long-standing AS, who presented with purulent sputum, fever and weight loss. a-c CT scans at 3 levels showing fibrobullous involvement of the right upper lobe associated with pleural thickening and traction of the trachea. d-f Eight months later, an extensive thickwalled cavity is evident at the apex of the right upper lobe containing amorphous material. Bronchoalveolar lavage cultures grew Aspergillus fumigatus. 
Table 2. Respiratory involvement in CTDs

\begin{tabular}{|c|c|c|c|c|c|c|c|}
\hline Manifestation & RA & SLE & SS & DM-PM & $\begin{array}{l}\text { Sjögren's } \\
\text { syndrome }\end{array}$ & MCTD & AS \\
\hline Pleural effusion & ++ & ++ & \pm & - & \pm & + & - \\
\hline Pleural fibrosis & + & - & - & - & - & - & - \\
\hline Pneumothorax & + & - & - & - & \pm & - & + \\
\hline Pneumomediastinum & - & - & - & + & - & - & - \\
\hline Upper airway involvement & + & - & - & - & ++ & - & + \\
\hline Bronchiolitis/bronchiectasis & +++ & + & + & - & + & + & $-/ \pm$ \\
\hline UIP & ++ & + & + & ++ & $-/ \pm$ & + & + \\
\hline NSIP & + & + & +++ & +++ & $-/ \pm$ & ++ & + \\
\hline Apical fibrobullous disease & \pm & - & \pm & - & - & \pm & ++ \\
\hline LIP & $-/ \pm$ & $-/ \pm$ & $-/ \pm$ & - & + & - & - \\
\hline Lymphoproliferative disorders & \pm & - & - & - & + & - & - \\
\hline CPFE & + & - & \pm & - & - & \pm & \pm \\
\hline DIP/RB-ILD & + & - & + & - & - & - & - \\
\hline $\mathrm{COP} / \mathrm{AFOP}$ & + & + & + & ++ & + & + & - \\
\hline Eosinophilic pneumonia & $-/ \pm$ & - & - & - & - & - & - \\
\hline $\mathrm{DAD} / \mathrm{ARDS}$ & + & ++ & + & ++ & - & + & - \\
\hline Pulmonary nodules & + & - & - & - & - & - & - \\
\hline Pulmonary infections & + & +++ & + & + & \pm & + & + \\
\hline Aspiration pneumonia & - & - & ++ & ++ & - & + & \pm \\
\hline Lung cancer & - & - & ++ & ++ & - & + & - \\
\hline Pulmonary amyloidosis & $-/ \pm$ & - & - & - & - & - & - \\
\hline $\mathrm{PAH}$ & + & + & ++ & + & - & ++ & \pm \\
\hline $\mathrm{DAH} /$ capillaritis & $-/ \pm$ & + & $-/ \pm$ & $-/ \pm$ & - & \pm & - \\
\hline Vasculitis & + & + & - & + & - & + & \pm \\
\hline Pulmonary thromboembolism & + & ++ & + & \pm & - & + & - \\
\hline Acute reversible hypoxemia & - & + & - & - & - & - & - \\
\hline Respiratory muscle dysfunction & $-/ \pm$ & + & - & ++ & - & - & \pm \\
\hline Thoracic cage involvement & \pm & $-/ \pm$ & - & \pm & - & - & + \\
\hline Obstructive sleep apnea & \pm & - & - & - & - & - & ++ \\
\hline
\end{tabular}

Relative frequencies:,,,++++++ \pm and - . AS $=$ Ankylosing spondylitis; CPFE $=$ combined pulmonary fibrosis and emphysema; DIP = desquamative interstitial pneumonia; RB-ILD = respiratory bronchiolitis interstitial lung disease; $\mathrm{AFOP}=$ acute fibrinous and organizing pneumonia; $\mathrm{DAD}=$ diffuse alveolar damage; $\mathrm{ARDS}=$ acute respiratory distress syndrome.

perfusion of the upper lung segments due to thoracic cage dysmobility, altered upper lung mechanical stress, recurrent upper lobe infections due to impaired cough and upper airway secretion clearance, and small airway obstruction [231, 249]. Apical fibrobullous disease may be complicated by spontaneous pneumothorax or cyst superinfection by fungi or mycobacteria [250]. Lung involvement is rarely so severe as to lead to respiratory failure. Cricoarytenoid arthritis has also been described [236].

\section{Obstructive Sleep Apnea Syndrome}

The prevalence of OSAS in ankylosing spondylitis patients is higher than reported in the general population $[240,241]$. The pathogenetic mechanisms may include restriction of the oropharyngeal airway by compression from cervical spine involvement or temporomandibular involvement, cervical spine disease causing compression of the respiratory centers found in the medulla resulting in central depression of respiration, or restrictive pulmonary disease [240]. Symptoms include daytime fatigue and snoring [241]. Given the increased incidence of OSAS in patients with advanced ankylosing spondylitis, formal sleep evaluation should be considered in patients complaining of severe fatigue, especially older patients (35 years of age or more) and with a disease duration longer than 5 years. Treatment of OSAS in ankylosing spondylitis is the same as for patients without ankylosing spondylitis and includes continuous positive airway pressure and smoking cessation $[231,241,251]$. 


\section{Acknowledgments}

The authors would like to acknowledge the precious help in the preparation of the figures concerning the case presentations of the paper and sincerely thank the following doctors: (1) Stylianos Argentos, 2nd Radiology Department, 'Attikon' University Hospital, National and Kapodistrian University Athens Medical School, Greece; (2) John Panayiotides, 2nd Department of Pathology, 'At- tikon' University Hospital, National and Kapodistrian University Athens Medical School, Greece; (3) Iraklis Tsangaris, 2nd Critical Care Department, 'Attikon' University Hospital, National and Kapodistrian University Athens Medical School, Greece; (4) Thomas Raptakis, 2nd Department of Pneumonology, 'Attikon' University Hospital, National and Kapodistrian University Athens Medical School, Greece; (5) Dimitra Rontogianni, Department of Pathology, Evangelismos Athens Hospital, Greece.

\section{References}

1 Antin-Ozerkis D, Swigris J: Pulmonary complications of connective tissue disease. Semin Respir Crit Care Med 2014;35:157-158.

2 Assayag D, Ryerson CJ: Determining respiratory impairment in connective tissue diseaseassociated interstitial lung disease. Rheum Dis Clin North Am 2015;41:213-223.

3 Capobianco J, Grimberg A, Thompson BM, Antunes VB, Jasinowodolinski D, Meirelles GS: Thoracic manifestations of collagen vascular diseases. Radiographics 2012;32:33-50.

4 Jacob J, Nair A, Hansell DM: High-resolution computed tomography of the pulmonary manifestations of connective tissue diseases. Semin Respir Crit Care Med 2014;35:166-180.

5 Wells AU, Denton CP: Interstitial lung disease in connective tissue disease - mechanisms and management. Nat Rev Rheumatol 2014; 10:728-739.

6 Higashiguchi M, Kijima T, Sumikawa $\mathrm{H}$ Honda $\mathrm{O}$, Minami T, Hirata $\mathrm{H}$, Inoue $\mathrm{K}, \mathrm{Na}-$ gatomo I, Takeda $\mathrm{Y}$, Kida $\mathrm{H}$, Tomiyama $\mathrm{N}$, Kumanogoh A: A retrospective study of prognostic factors in patients with interstitial pneumonia receiving long-term oxygen therapy. Lung 2014;192:729-737.

7 Nikpour M, Baron M: Mortality in systemic sclerosis: lessons learned from populationbased and observational cohort studies. Curr Opin Rheumatol 2014;26:131-137.

8 Horvath IF, Szanto A, Papp G, Zeher M: Clinical course, prognosis, and cause of death in primary Sjögren's syndrome. J Immunol Res 2014;2014:647507.

9 Humphreys JH, Warner A, Chipping J, Marshall T, Lunt M, Symmons DP, Verstappen SM: Mortality trends in patients with early rheumatoid arthritis over 20 years: results from the Norfolk Arthritis Register. Arthritis Care Res (Hoboken) 2014;66:1296-1301.

10 Lerang K, Gilboe IM, Steinar Thelle D, Gran JT: Mortality and years of potential life loss in systemic lupus erythematosus: a populationbased cohort study. Lupus 2014;23:15461552.

11 Santo AH, Souza JM, Pinheiro CE, Souza DC, Sato EI: Trends in dermatomyositis- and polymyositis-related mortality in the state of São Paulo, Brazil, 1985-2007: multiple causeof-death analysis. BMC Public Health 2010; 10:597.
12 Bakland G, Gran JT, Nossent JC: Increased mortality in ankylosing spondylitis is related to disease activity. Ann Rheum Dis 2011;70: 1921-1925.

13 Hajas A, Szodoray P, Nakken B, Gaal J, Zöld E, Laczik R, Demeter N, Nagy G, Szekanecz Z, Zeher M, Szegedi G, Bodolay E: Clinical course, prognosis, and causes of death in mixed connective tissue disease. J Rheumatol 2013;40:1134-1142.

14 Agmon-Levin N, Damoiseaux J, Kallenberg C, Sack U, Witte T, Herold M, Bossuyt X, Musset L, Cervera R, Plaza-Lopez A, Dias C, Sousa MJ, Radice A, Eriksson C, Hultgren O, Viander M, Khamashta M, Regenass S, Andrade LE, Wiik A, Tincani A, Rönnelid J, Bloch DB, Fritzler MJ, Chan EK, Garcia-De La Torre I, Konstantinov KN, Lahita R, Wilson M, Vainio O, Fabien N, Sinico RA, Meroni P, Shoenfeld Y: International recommendations for the assessment of autoantibodies to cellular antigens referred to as anti-nuclear antibodies. Ann Rheum Dis 2014;73:17-23.

15 Mahler M, Meroni PL, Bossuyt X, Fritzler MJ: Current concepts and future directions for the assessment of autoantibodies to cellular antigens referred to as anti-nuclear antibodies. J Immunol Res 2014;2014:315179.

16 Rehman HU: Antinuclear antibodies: when to test and how to interpret findings. J Fam Prac 2015;64:E5-E8.

17 Wuyts WA, Cavazza A, Rossi G, Bonella F, Sverzellati N, Spagnolo P: Differential diagnosis of usual interstitial pneumonia: when is it truly idiopathic? Eur Respir Rev 2014;23: 308-319.

18 Antoniou KM, Margaritopoulos G, Economidou F, Siafakas NM: Pivotal clinical dilemmas in collagen vascular diseases associated with interstitial lung involvement. Eur Respir J 2009:33:882-896.

19 Tzelepis GE, Toya SP, Moutsopoulos HM: Occult connective tissue diseases mimicking idiopathic interstitial pneumonias. Eur Respir J 2008;31:11-20.

20 Kim HC, Ji W, Kim MY, Colby TV, Jang SJ, Lee CK, Han SB, Kim DS: Interstitial pneumonia related to undifferentiated connective tissue disease: pathologic pattern and prognosis. Chest 2015;147:165-172.
21 Papiris SA, Kagouridis K, Bouros D: Serologic evaluation in idiopathic interstitial pneumonias. Curr Opin Pulm Med 2012;18:433-440.

22 Corte TJ, Copley SJ, Desai SR, Zappala CJ, Hansell DM, Nicholson AG, Colby TV, Renzoni E, Maher TM, Wells AU: Significance of connective tissue disease features in idiopathic interstitial pneumonia. Eur Respir J 2012; 39:661-668.

23 Scott DL, Wolfe F, Huizinga TW: Rheumatoid arthritis. Lancet 2010;376:1094-1108.

24 Song YW, Kang EH: Autoantibodies in rheumatoid arthritis: rheumatoid factors and anticitrullinated protein antibodies. Q J Med 2010;103:139-146.

25 Lake F, Proudman S: Rheumatoid arthritis and lung disease: from mechanisms to a practical approach. Semin Respir Crit Care Med 2014;35:222-238.

26 Yunt ZX, Solomon JJ: Lung disease in rheumatoid arthritis. Rheum Dis Clin North Am 2015;41:225-236.

27 Brown KK: Rheumatoid lung disease. Proc Am Thorac Soc 2007;4:443-448.

28 Fischer A, Cosgrove GP: Interstitial lung abnormalities in rheumatoid arthritis are common and important. Chest 2014;146:8-10.

29 Vivero M, Padera RF: Histopathology of lung diseases in the connective tissue diseases. Rheum Dis Clin North Am 2015;41:197-211.

30 Kelly CA, Saravanan V, Nisar M, Arthanari S, Woodhead FA, Price-Forbes AN, Dawson J, Sathi N, Ahmad Y, Koduri G, Young A; British Rheumatoid Interstitial Lung (BRILL) Network: Rheumatoid arthritis-related interstitial lung disease: associations, prognostic factors and physiological and radiological characteristics - a large multicentre UK study. Rheumatology (Oxford) 2014;53:1676-1682.

31 Solomon JJ, Ryu JH, Tazelaar HD, Myers JL, Tuder R, Cool CD, Curran-Everett D, Fischer A, Swigris JJ, Brown KK: Fibrosing interstitial pneumonia predicts survival in patients with rheumatoid arthritis-associated interstitial lung disease (RA-ILD). Respir Med 2013;107: 1247-1252.

32 Antoniou KM, Mamoulaki M, Malagari K, Kritikos HD, Bouros D, Siafakas NM, Boumpas DT: Infliximab therapy in pulmonary fibrosis associated with collagen vascular disease. Clin Exp Rheumatol 2007;25:23-28. 
33 Assayag D, Elicker BM, Urbania TH, Colby TV, Kang BH, Ryu JH, King TE, Collard HR, Kim DS, Lee JS: Rheumatoid arthritis-associated interstitial lung disease: radiologic identification of usual interstitial pneumonia pattern. Radiology 2014;270:583-588.

34 Lee HK, Kim DS, Yoo B, Seo JB, Rho JY, Colby TV, Kitaichi M: Histopathologic pattern and clinical features of rheumatoid arthritisassociated interstitial lung disease. Chest 2005;127:2019-2027.

35 Smith M, Dalurzo M, Panse P, Parish J, Leslie $\mathrm{K}$ : Usual interstitial pneumonia-pattern fibrosis in surgical lung biopsies. Clinical, radiological and histopathological clues to aetiology. J Clin Pathol 2013;66:896-903.

36 Du Bois R, King TE Jr: Challenges in pulmonary fibrosis. 5 . The NSIP/UIP debate. Tho$\operatorname{rax} 2007 ; 62: 1008-1112$.

37 Jani M, Hirani N, Matteson EL, Dixon WG: The safety of biologic therapies in RA-associated interstitial lung disease. Nat Rev Rheumatol 2014;10:284-294.

38 Vij R, Strek ME: Diagnosis and treatment of connective tissue disease-associated interstitial lung disease. Chest 2013;143:814-824

39 De Lauretis A, Veeraraghavan S, Renzoni E: Review series: aspects of interstitial lung disease: connective tissue disease-associated interstitial lung disease: how does it differ from IPF? How should the clinical approach differ? Chron Respir Dis 2011;8:53-82.

40 Henriet AC, Diot E, Marchand-Adam S, de Muret A, Favelle O, Crestani B, Diot P: Organising pneumonia can be the inaugural manifestation in connective tissue diseases, including Sjögren's syndrome. Eur Respir Rev 2010;19:161-163.

41 Papiris SA, Maniati MA, Kalousis JV, Constantopoulos $\mathrm{SH}$ : Chronic eosinophilic pneumonia in rheumatoid arthritis. Monaldi Arch Chest Dis 1995;50:360-362.

42 Tazelaar HD, Wright JL, Churg A: Desquamative interstitial pneumonia. Histopathology 2011;58:509-516.

43 Sigala I, Kalomenidis I, Malagari K, Rontogianni D, Kapotsis G, Vassilakopoulos T, Roussos C, Papiris SA: Dry cough and dyspnoea rapidly increasing to respiratory failure in a male smoker. Eur Respir J 2005;25:11221125.

44 Swartz MA, Vivino FB: Dramatic reversal of lymphocytic interstitial pneumonitis in Sjögren's syndrome with rituximab. J Clin Rheumatol 2011;17:454.

45 Cottin V, Nunes H, Mouthon L, Gamondes D, Lazor R, Hachulla E, Revel D, Valeyre D, Cordier JF; Groupe d'Etudes et de Recherche sur les Maladies 'Orphelines' Pulmonaires: Combined pulmonary fibrosis and emphysema syndrome in connective tissue disease. Arthritis Rheum 2011;63:295-304

46 Balbir-Gurman A, Yigla M, Nahir AM, Braun-Moscovici Y: Rheumatoid pleural effusion. Semin Arthritis Rheum 2006;35:368378.

Lung Involvement in Rheumatologic Disease
47 Anevlavis S, Tzouvelekis A, Bouros D: Mechanisms of pleural involvement in orphan diseases. Respiration 2012;83:5-12

48 Bouros D, Pneumatikos I, Tzouvelekis A: Pleural involvement in systemic autoimmune disorders. Respiration 2008;75:361-371.

49 Avnon LS, Abu-Shakra M, Flusser D, Heimer D, Sion-Vardy N: Pleural effusion associated with rheumatoid arthritis: what cell predominance to anticipate? Rheumatol Int 2007;27: 919-925.

50 Naylor B: The pathognomonic cytologic picture of rheumatoid pleuritis. The $1989 \mathrm{Mau}-$ rice Goldblatt Cytology award lecture. Acta Cytol 1990;34:465-473.

51 Genzen JR, Motin A: Cholesterol crystals in pleural fluid. Am J Respir Crit Care Med 2012; 185:586.

52 Ahmed R, Ahmed U, Syed I: Pneumothorax necessitans in a patient with trapped lung and rheumatoid arthritis. BMJ Case Rep 2013; 2013i:bcr2013009263.

53 Rueth N, Andrade R, Groth S, D'Cunha J, Maddaus M: Pleuropulmonary complications of rheumatoid arthritis: a thoracic surgeon's challenge. Ann Thorac Surg 2009; 88:e20-e21.

54 Kobayashi T, Satoh K, Ohkawa M, Satoh A: Multiple rheumatoid nodules with rapid thinwalled cavity formation producing pneumothorax. J Thorac Imag 2005;20:47-49.

55 Wilsher M, Voight L, Milne D, Teh M, Good N, Kolbe J, Williams M, Pui K, Merriman T, Sidhu K, Dalbeth N: Prevalence of airway and parenchymal abnormalities in newly diagnosed rheumatoid arthritis. Respir Med 2012; 106:1441-1446

56 Demoruelle MK, Weisman MH, Simonian PL, Lynch DA, Sachs PB, Pedraza IF, Harrington AR, Kolfenbach JR, Striebich CC, Pham QN, Strickland CD, Petersen BD, Parish MC, Derber LA, Norris JM, Holers VM, Deane KD: Brief report: airways abnormalities and rheumatoid arthritis-related autoantibodies in subjects without arthritis: early injury or initiating site of autoimmunity? Arthritis Rheum 2012;64:1756-1761.

57 Geri G, Dadoun S, Bui T, Del Castillo Pinol N, Paternotte S, Dougados M, Gossec L: Risk of infections in bronchiectasis during diseasemodifying treatment and biologics for rheumatic diseases. BMC Infect Dis 2011;11:304.

58 Puéchal X, Génin E, Bienvenu T, Le Jeunne C, Dusser DJ: Poor survival in rheumatoid arthritis associated with bronchiectasis: a family-based cohort study. PLoS One 2014;9: e110066.

59 Devouassoux G, Cottin V, Lioté H, Marchand E, Frachon I, Schuller A, Béjui-Thivolet F, Cordier JF; Groupe d'Etudes et de Recherche sur les Maladies 'Orphelines' Pulmonaires: Characterisation of severe obliterative bronchiolitis in rheumatoid arthritis. Eur Respir J 2009;33:1053-1061.

60 Hamdan AL, Sarieddine D: Laryngeal manifestations of rheumatoid arthritis. Autoimmune Dis 2013;2013:103081.
61 Peters JE, Burke CJ, Morris VH: Three cases of rheumatoid arthritis with laryngeal stridor. Clin Rheumatol 2011;30:723-727.

62 Beumer HM, van Belle CJ: Pulmonary nodules in rheumatoid arthritis. Respiration 1972;29:556-564.

63 Gómez Herrero H, Arraiza Sarasa M, Rubio Marco I, García de Eulate Martín-Moro I: Pulmonary rheumatoid nodules: presentation, methods, diagnosis and progression in reference to 5 cases. Rheumatol Clin 2012;8: 212-215.

64 Highton J, Hessian PA, Stamp L: The rheumatoid nodule: peripheral or central to rheumatoid arthritis? Rheumatology (Oxford) 2007; 46:1385-1387.

65 Saraya T, Tanaka R, Fujiwara M, Koji H, Oda M, Ogawa Y, Nagatomo T, Watanabe M, Yokoyama T, Ishii $\mathrm{H}$, Takei $\mathrm{H}$, Goya T, Takizawa $\mathrm{H}$, Goto H: Fluorodeoxyglucose (FDG) uptake in pulmonary rheumatoid nodules diagnosed by video-assisted thoracic surgery lung biopsy: two case reports and a review of the literature. Mod Rheumatol 2013;23:393-396.

66 Schreiber J, Koschel D, Kekow J, Waldburg N, Goette A, Merget R: Rheumatoid pneumoconiosis (Caplan's syndrome). Eur J Intern Med 2010;21:168-172.

67 Shariff N, Kumar A, Narang R, Malhotra A, Mukhopadhyaya S, Sharma SK: A study of pulmonary arterial hypertension in patients with rheumatoid arthritis. Int J Cardiol 2007; 115:75-76.

68 Chung WS, Peng CL, Lin CL, Chang YJ, Chen YF, Chiang JY, Sung FC, Kao CH: Rheumatoid arthritis increases the risk of deep vein thrombosis and pulmonary thromboembolism: a nationwide cohort study. Ann Rheum Dis 2014;73:1774-1780.

69 Sadeghi S, Granton JT, Akhavan P, Pasarikovski CR, Roos AM, Thenganatt J, Moric J, Johnson SR: Survival in rheumatoid arthritis-associated pulmonary arterial hypertension compared with idiopathic pulmonary arterial hypertension. Respirology 2015;20: 481-487.

70 Bély M, Apáthy A: Amyloid A deposition in rheumatoid arthritis: a retrospective clinicopathologic study of 161 autopsy patients. Amyloid 2012;19:212-213.

71 Schwarz MI, Zamora MR, Hodges TN, Chan ED, Bowler RP, Tuder RM: Isolated pulmonary capillaritis and diffuse alveolar hemorrhage in rheumatoid arthritis and mixed connective tissue disease. Chest 1998;113:16091615.

72 Tsokos GC: Systemic lupus erythematosus. N Engl J Med 2011;365:2110-2121.

73 Compagno $\mathrm{M}$, Rekvig OP, Bengtsson AA, Sturfelt G, Heegaard NH, Jönsen A, Jacobsen RS, Eilertsen GØ, Fenton CG, Truedsson L, Nossent JC, Jacobsen S: Clinical phenotype associations with various types of anti-dsDNA antibodies in patients with recent onset of rheumatic symptoms. Results from a multicentre observational study. Lupus Sci Med 2014;1:e000007. 
74 Rekvig OP, Van der Vlag J: The pathogenesis and diagnosis of systemic lupus erythematosus: still not resolved. Semin Immunopathol 2014;36:301-311.

75 Mittoo S, Fell CD: Pulmonary manifestations of systemic lupus erythematosus. Semin Respir Crit Care Med 2014;35:249-254.

76 Allen D, Fischer A, Bshouty Z, Robinson DB, Peschken CA, Hitchon C, El-Gabalawy H, Meyers M, Mittoo S: Evaluating systemic lupus erythematosus patients for lung involvement. Lupus 2012;21:1316-1325.

77 Lisnevskaia L, Murphy G, Isenberg D: Systemic lupus erythematosus. Lancet 2014;384: 1878-1888.

78 Weng CT, Chung TJ, Liu MF, Weng MY, Lee $\mathrm{CH}$, Chen JY, Wu AB, Lin BW, Luo CY, Hsu SC, Lee BF, Tsai HM, Chao SC, Wang JY, Chen TY, Chen CW, Chang HY, Wang CR: A retrospective study of pulmonary infarction in patients with systemic lupus erythematosus from southern Taiwan. Lupus 2011;20:876885.

79 Kim JS, Lee KS, Koh EM, Kim SY, Chung MP, Han J: Thoracic involvement of systemic lupus erythematosus: clinical, pathologic, and radiologic findings. J Comput Assist Tomogr 2000;24:9-18.

80 Zandman-Goddard G, Shoenfeld Y: SLE and infections. Clin Rev Allergy Immunol 2003; 25:29-40.

81 Cuchacovich R, Gedalia A: Pathophysiology and clinical spectrum of infections in systemic lupus erythematosus. Rheum Dis Clin North Am 2009;35:75-93.

82 Feldman CH, Hiraki LT, Winkelmayer WC, Marty FM, Franklin JM, Kim SC, Costenbader KH: Serious infections among adult Medicaid beneficiaries with systemic lupus erythematosus and lupus nephritis. Arthritis Rheumatol 2015;67:1577-1585.

83 Tektonidou MG, Wang Z, Dasgupta A, Ward MM: Burden of serious infections in adults with systemic lupus erythematosus. A national population-based study, 1996-2011. Arthritis Care Res (Hoboken) 2015, Epub ahead of print.

84 Danza A, Ruiz-Irastorza G: Infection risk in systemic lupus erythematosus patients: susceptibility factors and preventive strategies. Lupus 2013;22:1286-1294.

85 Hellmann DB, Petri M, Whiting-O'Keefe Q: Fatal infections in systemic lupus erythematosus: the role of opportunistic organisms. Medicine (Baltimore) 1987;66:341348.

86 Palavutitotai N, Buppajarntham T, Katchamart W: Etiologies and outcomes of pleural effusions in patients with systemic lupus erythematosus. J Clin Rheumatol 2014;20: 418-421.

87 Torre O, Harari S: Pleural and pulmonary involvement in systemic lupus erythematosus. Presse Méd 2011;40:e19-e29.

88 Wang DY: Diagnosis and management of lupus pleuritis. Curr Opin Pulm Med 2002;8: 312-316.
89 Bouros D, Panagou P, Papandreou L, Kottakis I, Tegos C: Massive bilateral pleural effusion as the only first presentation of systemic lupus erythematosus. Respiration 1992;59:173-175.

90 Man BL, Mok CC: Serositis related to systemic lupus erythematosus: prevalence and outcome. Lupus 2005;14:822-826.

91 Sarzi-Puttini P, Atzeni F, Capsoni F, Lubrano E, Doria A: Drug-induced lupus erythematosus. Autoimmunity 2005;38:507-518.

92 Bazzan M, Vaccarino A, Marletto F: Systemic lupus erythematosus and thrombosis. Thromb J 2015; 13:16.

93 Sallai KK, Nagy E, Bodó I, Mohl A, Gergely $\mathrm{P}$ : Thrombosis risk in systemic lupus erythematosus: the role of thrombophilic risk factors. Scand J Rheumatol 2007;36:198-205.

94 Ruiz-Irastorza G, Crowther M, Branch W, Khamashta MA: Antiphospholipid syndrome. Lancet 2010;376:1498-1509.

95 Schreiber BE, Connolly MJ, Coghlan JG: Pulmonary hypertension in systemic lupus erythematosus. Best Pract Res Clin Rheumatol 2013;27:425-434.

96 Wiedermann FJ, Lederer W, Sepp N, Schobersberger W: ARDS in catastrophic antiphospholipid syndrome. Lupus 2001;10: 382-383.

97 Cervera R, Serrano R, Pons-Estel GJ, Ceberio-Hualde L, Shoenfeld Y, de Ramón E, Buonaiuto V, Jacobsen S, Zeher MM, Tarr T, Tincani A, Taglietti M, Theodossiades G, Nomikou E, Galeazzi M, Bellisai F, Meroni PL, Derksen RH, de Groot PG, Baleva M, Mosca M, Bombardieri S, Houssiau F, Gris JC, Quéré I, Hachulla E, Vasconcelos C, Fernández-Nebro A, Haro M, Amoura Z, et al: Morbidity and mortality in the antiphospholipid syndrome during a 10 -year period: a multicentre prospective study of $1,000 \mathrm{pa}-$ tients. Ann Rheum Dis 2015;74:1011-1018.

98 Miyakis S, Lockshin MD, Atsumi T, Branch DW, Brey RL, Cervera R, Derksen RH, de Groot PG, Koike T, Meroni PL, Reber G, Shoenfeld Y, Tincani A, Vlachoyiannopoulos PG, Krilis SA: International consensus statement on an update of the classification criteria for definite antiphospholipid syndrome (APS). J Thromb Haemost 2006;4: 295-306.

99 Keeling D, Mackie I, Moore GW, Greer IA, Greaves M; British Committee for Standards in Haematology: Guidelines on the investigation and management of antiphospholipid syndrome. Br J Haematol 2012;157:4758.

100 Zöller B, Li X, Sundquist J, Sundquist K: Risk of pulmonary embolism in patients with autoimmune disorders: a nationwide followup study from Sweden. Lancet 2012;379: 244-249.

101 Konstantinides SV, Torbicki A, Agnelli G, Danchin N, Fitzmaurice D, Galiè N, Gibbs JS, Huisman MV, Humbert M, Kucher N, Lang I, Lankeit M, Lekakis J, Maack C, Mayer E, Meneveau N, Perrier A, Pruszczyk P,
Rasmussen LH, Schindler TH, Svitil P, Vonk Noordegraaf A, Zamorano JL, Zompatori M; Task Force for the Diagnosis and Management of Acute Pulmonary Embolism of the European Society of Cardiology (ESC) 2014 ESC guidelines on the diagnosis and management of acute pulmonary embolism. Eur Heart J 2014;35:3033-3069.

102 Lang IM, Pesavento R, Bonderman D, Yuan JX: Risk factors and basic mechanisms of chronic thromboembolic pulmonary hypertension: a current understanding. Eur Respir J 2013;41:462-468.

103 Kim NH, Delcroix M, Jenkins DP, Channick R, Dartevelle P, Jansa P, Lang I, Madani MM, Ogino $\mathrm{H}$, Pengo V, Mayer E: Chronic thromboembolic pulmonary hypertension. J Am Coll Cardiol 2013;62:D92-D99.

104 Galiè N, Corris PA, Frost A, Girgis RE, Granton J, Jing ZC, Klepetko W, McGoon MD, McLaughlin VV, Preston IR, Rubin LJ, Sandoval J, Seeger W, Keogh A: Updated treatment algorithm of pulmonary arterial hypertension. J Am Coll Cardiol 2013; 62:D60-D72.

105 Cervera R, Rodríguez-Pintó I, Espinosa G Task Force on Catastrophic Antiphospholipid Syndrome: Catastrophic antiphospholipid syndrome: task force report summary. Lupus 2014;23:1283-1285.

106 Zamora MR, Warner ML, Tuder R, Schwarz MI: Diffuse alveolar hemorrhage and systemic lupus erythematosus. Clinical presentation, histology, survival, and outcome. Medicine (Baltimore) 1997;76:192-202.

107 Kwok SK, Moon SJ, Ju JH, Park KS, Kim WU, Cho CS, Kim HY, Park SH: Diffuse alveolar hemorrhage in systemic lupus erythematosus: risk factors and clinical outcome: results from affiliated hospitals of Catholic University of Korea. Lupus 2011;20:102107.

108 Gutsche M, Rosen GD, Swigris JJ: Connective tissue disease-associated interstitial lung disease: a review. Curr Respir Care Rep 2012; 1:224-232.

109 Reynolds JA, Toescu V, Yee CS, Prabu A, Situnayake D, Gordon C: Effects of rituximab on resistant SLE disease including lung involvement. Lupus 2009;18:67-73.

110 Papiris SA, Kagouridis K, Papadaki G, Kolilekas L, Manali ED: Treating CTDs related fibrotic ILDs by the immunosuppressants: 'facts and faults'. Lung 2014;192:221-223.

111 Warrington KJ, Moder KG, Brutinel WM: The shrinking lungs syndrome in systemic lupus erythematosus. Mayo Clin Proc 2000; $75: 467-472$

112 Carmier D, Diot E, Diot P: Shrinking lung syndrome: recognition, pathophysiology and therapeutic strategy. Expert Rev Respir Med 2011;5:33-39.

113 Peñacoba Toribio P, Córica Albani ME Mayos Pérez M, Rodríguez de la Serna A: Rituximab in the treatment of shrinking lung syndrome in systemic lupus erythematosus. Rheumatol Clin 2014;10:325-327. 
114 Esmaeilbeigi F, Juvet S, Hwang D, Mittoo S: Desquamative interstitial pneumonitis and systemic lupus erythematosus. Can Respir J 2012;19:50-52.

115 Martens J, Demedts M, Vanmeenen MT, Dequeker J: Respiratory muscle dysfunction in systemic lupus erythematosus. Chest 1983;84:170-175.

116 Myers JL, Katzenstein AA: Microangiitis in lupus induced pulmonary hemorrhage. Am J Clin Pathol 1986;85:552-556.

117 Andonopoulos AP: Adult respiratory distress syndrome: an unrecognized premortem event in systemic lupus erythematosus. Br J Rheumatol 1991;30:346-348.

118 Simonson JS, Schiller NB, Petri M, Hellmann DB: Pulmonary hypertension in systemic lupus erythematosus. J Rheumatol 1989;16:918-925.

119 Abramson SB, Dobro J, Eberle MA, Benton M, Reibman J, Epstein H, Rapoport DM, Belmont HM, Goldring RM: Acute reversible hypoxemia in systemic lupus erythematosus. Ann Intern Med 1991;114:941-947.

120 Teitel AD, MacKenzie CR, Stern R, Paget SA: Laryngeal involvement in systemic lupus erythematosus. Semin Arthritis Rheum 1992;22:203-214.

121 Langford CA, Van Waes C: Upper airway obstruction in the rheumatic diseases. Rheum Dis Clin North Am 1997;23:345363.

122 Keane MP, Lynch JP 3rd: Pleuropulmonary manifestations of systemic lupus erythematosus. Thorax 2000;55:159-166.

123 Lateef O, Shakoor N, Balk RA: Methotrexate pulmonary toxicity. Expert Opin Drug Saf 2005;4:723-730.

124 Tansey D, Wells AU, Colby TV, Nikolakoupolou A, du Bois RM, Hansell DM, Nicholson AG: Variations in histological patterns of interstitial pneumonia between connective tissue disorders and their relationship to prognosis. Histopathology 2004;44:585596.

125 Gammon RB, Bridges TA, al-Nezir H, Alexander CB, Kennedy JI Jr: Bronchiolitis obliterans organizing pneumonia associated with systemic lupus erythematosus. Chest 1992; 102:1171-1174.

126 Takada H, Saito Y, Nomura A, Ohga S, Kuwano K, Nakashima N, Aishima S, Tsuru N, Hara T: Bronchiolitis obliterans organizing pneumonia as an initial manifestation in systemic lupus erythematosus. Pediatr Pulmonol 2005;40:257-260.

127 Smith GA, Ward PH, Berci G: Laryngeal lupus erythematosus. J Laryngol Otol 1978;92: 67-73.

128 Hariri LP, Unizony S, Stone J, Mino-Kenudson M, Sharma A, Matsubara O, Mark EJ: Acute fibrinous and organizing pneumonia in systemic lupus erythematosus: a case report and review of the literature. Pathol Int 2010;60:755-759.
129 Sharma S, Smith R, Al-Hameed F: Fibrothorax and severe lung restriction secondary to lupus pleuritis and its successful treatment by pleurectomy. Can Respir J 2002;9:335337.

130 Shim SS, Chun EM, Sung SH: Unusual diffuse pulmonary amyloidosis in systemic lupus erythematosus: computed tomography findings. Clin Imaging 2011;35:156-159.

131 Cloutier BT, Clarke AE, Ramsey-Goldman R, Gordon C, Hansen JE, Bernatsky S: Systemic lupus erythematosus and malignancies: a review article. Rheum Dis Clin North Am 2014;40:497-506.

132 Gabrielli A, Avvedimento EV, Krieg T: Scleroderma. N Engl J Med 2009;360:1989-2003.

133 Van den Hoogen F, Khanna D, Fransen J, Johnson SR, Baron M, Tyndall A, MatucciCerinic M, Naden RP, Medsger TA Jr, Carreira PE, Riemekasten G, Clements PJ, Denton CP, Distler O, Allanore Y, Furst DE, Gabrielli A, Mayes MD, van Laar JM, Seibold JR, Czirjak L, Steen VD, Inanc M, KowalBielecka O, Müller-Ladner U, Valentini G, Veale DJ, Vonk MC, Walker UA, Chung L, et al: 2013 classification criteria for systemic sclerosis: an American College of Rheumatology/European League against Rheumatism collaborative initiative. Arthritis Rheum 2013;65:2737-2747.

134 Hachulla E, Launay D: Diagnosis and classification of systemic sclerosis. Clin Rev Allergy Immunol 2011;40:78-83.

135 Chaisson NF, Hassoun PM: Systemic sclerosis-associated pulmonary arterial hypertension. Chest 2013;144:1346-1356.

136 Tyndall A, Fistarol S: The differential diagnosis of systemic sclerosis. Curr Opin Rheumatol 2013;25:692-699.

137 Schoenfeld SR, Castelino FV: Interstitial lung disease in scleroderma. Rheum Dis Clin North Am 2015;41:237-248.

138 Wells AU: Interstitial lung disease in systemic sclerosis. Presse Méd 2014;43:e329e343.

139 Colaci M, Sebastiani M, Manfredi A, Giuggioli D, Cassone G, Manzini CU, Ghizzoni C, Cerri S, Ferri C: Lung involvement in systemic sclerosis: role of high resolution computed tomography and its relationship with other pulmonary and clinico-serological features. J Biol Regul Homeost Agents 2014; 28:481-488.

140 Frauenfelder T, Winklehner A, Nguyen TD, Dobrota R, Baumueller S, Maurer B, Distler O: Screening for interstitial lung disease in systemic sclerosis: performance of high-resolution CT with limited number of slices: a prospective study. Ann Rheum Dis 2014;73: 2069-2073.

141 Wells AU, Margaritopoulos GA, Antoniou $\mathrm{KM}$, Denton C: Interstitial lung disease in systemic sclerosis. Semin Respir Crit Care Med 2014;35:213-221.
142 Bouros D, Wells AU, Nicholson AG, Colby TV, Polychronopoulos V, Pantelidis $\mathrm{P}$, Haslam PL, Vassilakis DA, Black CM, du Bois RM: Histopathologic subsets of fibrosing alveolitis in patients with systemic sclerosis and their relationship to outcome. Am J Respir Crit Care Med 2002;165:1581-1586.

143 Bussone G, Mouthon L: Interstitial lung disease in systemic sclerosis. Autoimmun Rev 2011;10:248-255.

144 Ahmed SS, Johnson SR, Meaney C, Chau C, Marras TK: Lung function and survival in systemic sclerosis interstitial lung disease. J Rheumatol 2014;41:2326-2328.

145 Nihtyanova SI, Schreiber BE, Ong VH, Rosenberg D, Moinzadeh P, Coghlan JG, Wells AU, Denton CP: Prediction of pulmonary complications and long-term survival in systemic sclerosis. Arthritis Rheumatol 2014;66:1625-1635.

146 Battaglia S, Bellia M, Serafino-Agrusa L, Giardina A, Messina M, Cannizzaro F, Midiri M, Triolo G, Scichilone N: Physical capacity in performing daily activities is reduced in scleroderma patients with early lung involvement. Clin Respir J 2015, Epub ahead of print.

147 Someya F, Mugii N, Hasegawa M, Yahata T, Nakagawa T: Predictors of exercise-induced oxygen desaturation in systemic sclerosis patients with interstitial lung disease. Respir Care 2014;59:75-80.

148 Solomon JJ, Olson AL, Fischer A, Bull T, Brown KK, Raghu G: Scleroderma lung disease. Eur Respir Rev 2013;22:6-19.

149 Diab S, Dostrovsky N, Hudson M, Tatibouet S, Fritzler MJ, Baron M, Khalidi N; Canadian Scleroderma Research Group: Systemic sclerosis sine scleroderma: a multicenter study of 1,417 subjects. J Rheumatol 2014;41: 2179-2185.

150 Lo Monaco A, Govoni M, Trotta F: Digital clubbing or digital 'pseudoclubbing' in systemic sclerosis. J Clin Rheumatol 2006;12: 97.

151 Nihtyanova SI, Ong VH, Denton CP: Current management strategies for systemic sclerosis. Clin Exp Rheumatol 2014;32:156-164.

152 Simonneau G, Gatzoulis MA, Adatia I, Celermajer D, Denton C, Ghofrani A, Gomez Sanchez MA, Krishna Kumar R, Landzberg M, Machado RF, Olschewski H, Robbins IM, Souza R: Updated clinical classification of pulmonary hypertension. J Am Coll Cardiol 2013;62:D34-D41.

153 Chung L, Farber HW, Benza R, Miller DP, Parsons L, Hassoun PM, McGoon M, Nicolls MR, Zamanian RT: Unique predictors of mortality in patients with pulmonary arterial hypertension associated with systemic sclerosis in the REVEAL registry. Chest 2014;146:1494-1504.

154 Ghosh SK, Corkill MM, Hart HH, Ng KP Screening for pulmonary arterial hypertension in patients with scleroderma - a New Zealand perspective. NZ Med J 2014;127: 30-38.
Lung Involvement in Rheumatologic Disease 
155 Schwaiger JP, Khanna D, Gerry Coghlan J: Screening patients with scleroderma for pulmonary arterial hypertension and implications for other at-risk populations. Eur Respir Rev 2013;22:515-525.

156 Steen V, Medsger TA Jr: Predictors of isolated pulmonary hypertension in patients with systemic sclerosis and limited cutaneous involvement. Arthritis Rheum 2003;48: 516-522.

157 Kherbeck N, Tamby MC, Bussone G, Dib H, Perros F, Humbert M, Mouthon L: The role of inflammation and autoimmunity in the pathophysiology of pulmonary arterial hypertension. Clin Rev Allergy Immunol 2013; 44:31-38.

158 Prabu A, Gordon C: Pulmonary arterial hypertension in SLE: what do we know? Lupus 2013;22:1274-1285.

159 Highland KB: Recent advances in scleroderma-associated pulmonary hypertension. Curr Opin Rheumatol 2014;26:637-645.

160 Gashouta MA, Humbert M, Hassoun PM: Update in systemic sclerosis-associated pulmonary arterial hypertension. Presse Méd 2014;43:e293-e304.

161 Coghlan JG, Schreiber B: An update on the evaluation and management of pulmonary hypertension in scleroderma. Curr Rheumatol Rep 2012;14:1-10.

162 Launay D, Savale L, Berezne A, Le Pavec J, Hachulla E, Mouthon L, Sitbon O, Lambert B, Gaudric M, Jais X, Stephan F, Hatron PY, Lamblin N, Vignaux O, Cottin V, Farge D, Wallaert B, Guillevin L, Simonneau G, Mercier O, Fadel E, Dartevelle P, Humbert M, Mussot S; Working Group on Heart/Lung Transplantation in Systemic Sclerosis of the French Network on Pulmonary Hypertension: Lung and heart-lung transplantation for systemic sclerosis patients. A monocentric experience of 13 patients, review of the literature and position paper of a multidisciplinary Working Group. Presse Méd 2014; 43:e345-e363.

163 Roumm AD, Medsger TA Jr: Cancer and systemic sclerosis. Arthritis Rheum 1985;28: 1336-1340.

164 Rosenthal AK, McLaughlin JK, Gridley G, Nyren O: Incidence of cancer among patients with systemic sclerosis. Cancer 1995; 76:910-914.

165 Hill CL, Nguyen AM, Roder D, RobertsThomson P: Risk of cancer in patients with scleroderma: a population based cohort study. Ann Rheum Dis 2003;62:728-731.

166 Hant FN, Herpel LB, Silver RM: Pulmonary manifestations of scleroderma and mixed connective tissue disease. Clin Chest Med 2010;31:433-449.

167 Highland KB, Garin MC, Brown KK: The spectrum of scleroderma lung disease. Semin Respir Crit Care Med 2007;28:418-429.
168 Adzić TN, Pesut DP, Nagorni-Obradović LM, Stojsić JM, Vasiljević MD, Bouros D: Clinical features of lung cancer in patients with connective tissue diseases: a 10-year hospital based study. Respir Med 2008;102: 620-624.

169 Yang Y, Fujita J, Tokuda M, Bandoh S, Ishida T: Lung cancer associated with several connective tissue diseases: with a review of literature. Rheumatol Int 2001;21:106-111.

170 Kang KY, Yim HW, Kim IJ, Yoon JU, Ju JH, Kim HY, Park SH: Incidence of cancer among patients with systemic sclerosis in Korea: results from a single centre. Scand J Rheumatol 2009;38:299-303.

171 Peters-Golden M, Wise RA, Hochberg M, Stevens MB, Wigley FM: Incidence of lung cancer in systemic sclerosis. J Rheumatol 1985;12:1136-1139.

172 Bonifazi M, Tramacere I, Pomponio G, Gabrielli B, Avvedimento EV, La Vecchia C, Negri E, Gabrielli A: Systemic sclerosis (scleroderma) and cancer risk: systematic review and meta-analysis of observational studies. Rheumatology (Oxford) 2013;52: 143-154.

173 Daniels CE, Jett JR: Does interstitial lung disease predispose to lung cancer? Curr Opin Pulm Med 2005;11:431-437.

174 Ma Y, Seneviratne CK, Koss M: Idiopathic pulmonary fibrosis and malignancy. Curr Opin Pulm Med 2001;7:278-282.

175 Hazleman B: Incidence of neoplasms in patients with rheumatoid arthritis exposed to different treatment regimens. Am J Med 1985;78:39-43.

176 Archontogeorgis K, Steiropoulos P, Tzouvelekis A, Nena E, Bouros D: Lung cancer and interstitial lung diseases: a systematic review. Pulm Med 2012;2012:315918.

177 Dalakas MC: Inflammatory muscle diseases. N Engl J Med 2015;372:1734-1747.

178 Fathi M, Vikgren J, Boijsen M, Tylen U, Jorfeldt L, Tornling G, Lundberg IE: Interstitial lung disease in polymyositis and dermatomyositis: longitudinal evaluation by pulmonary function and radiology. Arthritis Rheum 2008;59:677-685.

179 Marie I, Hatron PY, Dominique S, Cherin P, Mouthon L, Menard JF: Short-term and long-term outcomes of interstitial lung disease in polymyositis and dermatomyositis: a series of 107 patients. Arthritis Rheum 2011; 63:3439-3447.

180 Kalluri M, Oddis CV: Pulmonary manifestations of the idiopathic inflammatory myopathies. Clin Chest Med 2010;31:501-512.

181 Cha SI, Fessler MB, Cool CD, Schwarz MI, Brown KK: Lymphoid interstitial pneumonia: clinical features, associations and prognosis. Eur Respir J 2006;28:364-369.

182 Beasley MB, Franks TJ, Galvin JR, Gochuico B, Travis WD: Acute fibrinous and organizing pneumonia: a histological pattern of lung injury and possible variant of diffuse alveolar damage. Arch Pathol Lab Med 2002; 126:1064-1070.
183 Schwarz MI, Sutarik JM, Nick JA, Leff JA, Emlen JW, Tuder RM: Pulmonary capillaritis and diffuse alveolar hemorrhage. A primary manifestation of polymyositis. Am J Respir Crit Care Med 1995;151:20372040.

184 Iijima Y, Furusawa H, Tateishi T, Tsuchiya K, Fujie T, Tamaoka M, Sakashita H, Miyazaki Y, Sumi Y, Hosono Y, Nakashima R, Mimori T, Inase N: Amyopathic dermatomyositis complicated with eosinophilic pneumonia. Intern Med 2014;53:15391544.

185 Tang R, Millett CR, Green JJ: Amyopathic dermatomyositis complicated by pneumomediastinum. J Clin Aesthet Dermatol 2013; 6:40-43.

186 Hamaguchi Y, Fujimoto M, Matsushita T, Kaji K, Komura K, Hasegawa M, Kodera M, Muroi E, Fujikawa K, Seishima M, Yamada H, Yamada R, Sato S, Takehara K, Kuwana $\mathrm{M}$ : Common and distinct clinical features in adult patients with anti-aminoacyltRNA synthetase antibodies: heterogeneity within the syndrome. PLoS One 2013; 8:e60442.

187 Fischer A, Swigris JJ, du Bois RM, Lynch DA, Downey GP, Cosgrove GP, Frankel SK, Fernandez-Perez ER, Gillis JZ, Brown KK: Antisynthetase syndrome in ANA and anti-Jo-1 negative patients presenting with idiopathic interstitial pneumonia. Respir Med 2009; 103:1719-1724.

188 Hozumi H, Enomoto N, Kono M, Fujisawa $\mathrm{T}$, Inui N, Nakamura $\mathrm{Y}$, Sumikawa $\mathrm{H}$, Johkoh T, Nakashima R, Imura Y, Mimori T, Suda T: Prognostic significance of antiaminoacyl-tRNA synthetase antibodies in polymyositis/dermatomyositis-associated interstitial lung disease: a retrospective case control study. PLoS One 2015; 10:e0120313.

189 Marie I, Josse S, Decaux O, Diot E, Landron C, Roblot P, Jouneau S, Hatron PY, Hachulla E, Vittecoq O, Menard JF, Jouen F, Dominique S: Clinical manifestations and outcome of anti-PL7 positive patients with antisynthetase syndrome. Eur J Intern Med 2013;24:474-479.

190 Váncsa A, Csípo I, Németh J, Dévényi K, Gergely L, Dankó K: Characteristics of interstitial lung disease in SS-A positive/Jo-1 positive inflammatory myopathy patients. Rheumatol Int 2009;29:989-994.

191 Suda T, Fujisawa T, Enomoto N, Nakamura $\mathrm{Y}$, Inui $\mathrm{N}$, Naito T, Hashimoto D, Sato J, Toyoshima M, Hashizume H, Chida K: Interstitial lung diseases associated with amyopathic dermatomyositis. Eur Respir J 2006; 28:1005-1012.

192 Ye S, Chen XX, Lu XY, Wu MF, Deng Y, Huang WQ, Guo Q, Yang CD, Gu YY, Bao CD, Chen SL: Adult clinically amyopathic dermatomyositis with rapid progressive interstitial lung disease: a retrospective cohort study. Clin Rheumatol 2007;26:16471654. 
193 Zou J, Guo Q, Chi J, Wu H, Bao C: HRCT score and serum ferritin level are factors associated to the 1-year mortality of acute interstitial lung disease in clinically amyopathic dermatomyositis patients. Clin Rheumatol 2015;34:707-714.

194 Labrador-Horrillo M, Martinez MA, SelvaO'Callaghan A, Trallero-Araguas E, Balada E, Vilardell-Tarres M, Juárez C: Anti-MDA5 antibodies in a large Mediterranean population of adults with dermatomyositis. J Immunol Res 2014;2014:290797.

195 Gono T, Kaneko H, Kawaguchi Y, Hanaoka M, Kataoka S, Kuwana M, Takagi K, Ichida H, Katsumata Y, Ota Y, Kawasumi H, Yamanaka $\mathrm{H}$ : Cytokine profiles in polymyositis and dermatomyositis complicated by rapidly progressive or chronic interstitial lung disease. Rheumatology (Oxford) 2014; 53:2196-2203.

196 Kawasumi H, Gono T, Kawaguchi Y, Kaneko H, Katsumata Y, Hanaoka M, Kataoka S, Yamanaka H: IL-6, IL-8, and IL-10 are associated with hyperferritinemia in rapidly progressive interstitial lung disease with polymyositis/dermatomyositis. Biomed Res Int 2014;2014:815245.

197 Fujisawa T, Hozumi H, Kono M, Enomoto $\mathrm{N}$, Hashimoto D, Nakamura Y, Inui N, Yokomura K, Koshimizu N, Toyoshima M, Shirai T, Yasuda K, Hayakawa H, Suda T: Prognostic factors for myositis-associated interstitial lung disease. PLoS One 2014; 9:e98824.

198 Moutsopoulos HM, Chused TM, Mann DL, Klippel JH, Fauci AS, Frank MM, Lawley TJ, Hamburger MI: Sjögren's syndrome (Sicca syndrome): current issues. Ann Intern Med 1980;92:212-226.

199 Moutsopoulos HM: Sjögren's syndrome: autoimmune epithelitis. Clin Immunol Immunopathol 1994;72:162-165.

200 Mitsias DI, Kapsogeorgou ED, Moutsopoulos HM: The role of epithelial cells in the initiation and perpetuation of autoimmune lesions: lessons from Sjögren's syndrome (autoimmune epithelitis). Lupus 2006;15: 255-261.

201 Triantafyllopoulou A, Tapinos N, Moutsopoulos HM: Evidence of coxsackie virus infection in primary Sjögren's syndrome. Arthritis Rheum 2004;50:2897-2902.

202 Bunim JJ, Talal N: The association of malignant lymphoma with Sjögren's syndrome. Trans Assoc Am Physicians 1963;76:45.

203 Kassan SS, Thomas TL, Moutsopoulos HM, Hoover R, Kimberly RP, Budman DR, Costa J, Decker JL, Chused TM: Increased risk of lymphoma in sicca syndrome. Ann Intern Med 1978;89:888-892.

204 Papiris SA, Kalomenidis I, Malagari K, Kapotsis GE, Harhalakis N, Manali ED, Rontogianni D, Roussos C, Moutsopoulos HM: Extranodal marginal zone B-cell lymphoma of the lung in Sjögren's syndrome patients: reappraisal of clinical, radiological, and pathology findings. Respir Med 2007;101:84-92.
205 Sjögren H: On knowledge of kerataconjunctivitis sicca. Keratitis filiformis due to lacrimal gland hypofunction. Acta Ophthalmol 1933;suppl 2:1-151.

206 Papiris SA, Moutsopoulos HM: Sjögren's syndrome and the lung; in Wells AU, Denton CP (eds): Handbook of Systemic Autoimmune Diseases. Amsterdam, Elsevier, 2004, vol 2, pp 161-180.

207 Papiris SA, Kassan S, Moutsopoulos HM The lung in Sjögren's syndrome. Semin Respir Crit Care Med 1999;20:179-184.

208 Papiris SA, Tsonis I, Moutsopoulos HM: Pulmonary complications in Sjögren's syndrome. Semin Respir Crit Care Med 2007; 28:459-472.

209 Constantopoulos SH, Papadimitriou CS, Moutsopoulos HM: Respiratory manifestations in primary Sjögren's syndrome: a clinical, functional and histologic study. Chest 1985;88:226-229.

210 Papathanasiou MP, Constantopoulos SH, Tsampoulas C: Reappraisal of respiratory abnormalities in primary and secondary Sjögren's syndrome. A controlled study. Chest 1986;90:370-374.

211 Papiris SA, Saetta M, Turato G, La Corte R, Trevisani L, Mapp CE, Maestrelli P, Fabbri L, Potena A: CD4 positive T-lymphocytes infiltrate the bronchial mucosa in patients with Sjögren's syndrome. Am J Respir Crit Care Med 1997;156:637-641.

212 Newball HH, Brahim SA: Chronic obstructive airway disease in patients with Sjögren's syndrome. Am Rev Respir Dis 1977;115:295.

213 Papiris SA, Maniati MA, Constantopoulos $\mathrm{SH}$, Roussos Ch, Moutsopoulos HM, Skopouli FN: Lung involvement in primary Sjögren's syndrome is mainly related to the small airway disease. Ann Rheum Dis 1999; 58:61-64.

214 Parambil JG, Myers JL, Lindell RM, Matteson EL, Ryu JH: Interstitial lung disease in primary Sjögren's syndrome. Chest 2006; 130:1489-1495.

215 Ito I, Nagai S, Kitaichi M, Nicholson AG, Johkoh T, Noma S, Kim DS, Handa T, Izumi T, Mishima M: Pulmonary manifestations of primary Sjögren's syndrome: a clinical, radiologic and pathologic study. Am J Respir Crit Care Med 2005;171:632-638.

216 Adzić TN, Stojsić JM, Radosavljević-Asić GD, Bouros D: Multinodular pulmonary amyloidosis in primary Sjögren's syndrome. Eur J Intern Med 2008;19:e97-e98.

217 Tani C, Carli L, Vagnani S, Talarico R, Baldini C, Mosca M, Bombardieri S: The diagnosis and classification of mixed connective tissue disease. J Autoimmun 2014;48-49: 46-49.

218 Mira-Avendano IC, Abril A: Pulmonary manifestations of Sjögren's syndrome, systemic lupus erythematosus and mixed connective tissue disease. Rheum Dis Clin North Am 2015;41:263-277.

219 Hant FN, Herpel LB, Silver RM: Pulmonary manifestations of scleroderma and connec- tive tissue disease. Clin Chest Med 2010;31: 433-449.

220 McBrien C, Penketh A, Johnson H, Nicholson AG, Wells A: Recurrent pneumothoraces in a 17-year-old man with mixed connective tissue disease. Thorax 2014;69:685-686.

221 Yang MC, Blutreich A, Das K: Nodular pulmonary amyloidosis with an unusual protein composition diagnosed by fine-needle aspiration biopsy: a case report. Diagn Cytopathol 2009;37:286-289.

222 Martens J, Demedts M: Diaphragm dysfunction in mixed connective tissue disease. A case report. Scand J Rheumatol 1982;11: 165-167.

223 Gunnarsson R, Aalokken TM, Molberg O, Lund MB, Mynarek GK, Lexberg AS, Time K, Dhainaut AS, Bertelsen LT, Palm O, Irgens K, Becker-Merok A, Nordeide JL, Johnsen V, Pedersen S, Prøven A, Garabet LS, Gran JT: Prevalence and severity of interstitial lung disease in mixed connective tissue disease: a nationwide, cross-sectional study. Ann Rheum Dis 2012;71:1966-1972.

224 Ortega-Hernandez OD, Shoenfeld Y: Mixed connective tissue disease: an overview of clinical manifestations, diagnosis and treatment. Best Pract Res Clin Rheumatol 2012; 26:61-72.

225 Kawano-Dourado L, Baldi BG, Kay FU, Dias OM, Gripp TE, Gomes PS, Fuller R, Caleiro MT, Kairalla RA, Carvalho CR: Pulmonary involvement in long-term mixed connective tissue disease: functional trends and image findings after 10 years. Clin Exp Rheumatol 2015;33:234-240.

226 Braun J, Sieper J: Ankylosing spondylitis. Lancet 2007;369:1379-1390.

227 Douganos M, Baeten D: Spondyloarthritis. Lancet 2011;377:2127-2137.

228 Durnham CL, Kautz FG: Spondyloarthritis ankylopoietica. A review and report of twenty cases. Am J Med Sci 1941;201:232-250.

229 Hamilton KA: Pulmonary disease manifestations of ankylosing spondylarthritis. Ann Intern Med 1949;31:216-227.

230 Daikh DI, Chen PP: Advances in managing ankylosing spondylitis. F1000Prime Rep 2014;6:78.

231 Kanathur N, Lee-Chiong T: Pulmonary manifestations of ankylosing spondylitis. Clin Chest Med 2010;31:547-554.

232 Romagnoli I, Gigliotti F, Galarducci A, Lanini B, Bianchi R, Cammelli D, Scano G Chest wall kinematics and respiratory muscle action in ankylosing spondylitis patients. Eur Respir J 2004;24:453-460.

233 Rumancik WM, Firooznia H, Davis MS, Leitman BS, Golimbu C, Rafii M, McCauley DI: Fibrobullous disease of the upper lobes: an extraskeletal manifestation of ankylosing spondylitis. J Comput Tomogr 1984;8:225229.

234 Blavia R, Toda MR, Vidal F, Benet A, Razquin S, Richart C: Pulmonary diffuse amyloidosis and ankylosing spondylitis. Chest 1992;102:1608-1610. 
235 Rosenow E, Strimlan CV, Muhm JR, Ferguson RH: Pleuropulmonary manifestations of ankylosing spondylitis. Mayo Clin Proc 1977;52:641-649.

236 Libby DM, Schley WS, Smith JP: Cricoarytenoid arthritis in ankylosing spondylitis. A cause of acute respiratory failure and cor pulmonale. Chest 1981;80:641-643.

237 Repo UK, Kentala E, Koistinen J, Lehtipuu AL, Miettinen A, Pyrhönen S, Tiilikainen A, Vuornos T: Pulmonary apical fibrocystic disease. Eur J Respir Dis 1981;62:46-55.

238 Ferdoutis M, Bouros D, Meletis G, Patsourakis G, Siafakas NM: Diffuse interstitial lung disease as an early manifestation of ankylosing spondylitis. Respiration 1995;62:286289.

239 Lee CC, Lee SH, Chang IJ, Lu TC, Yuan A, Chang TA, Tsai KC, Chen WJ: Spontaneous pneumothorax associated with ankylosing spondylitis. Rheumatology 2005;44:15381541.

240 Erb N, Karokis D, Delamere JP, Cushley MJ, Kitas GD: Obstructive sleep apnea as a cause of fatigue in ankylosing spondylitis. Ann Rheum Dis 2003;62:183-184.
241 Solak O, Fidan F, Dundar U, Türel A, Ayçiçek A, Kavuncu V, Unlü M: The prevalence of obstructive sleep apnea syndrome in ankylosing spondylitis patients. Rheumatology 2009;48:433-435.

242 Rhagae PK, Tarrasa BC: Bronchocentric granulomatosis and ankylosing spondylitis. Thorax 1984;39:317-318.

243 Turner JF, Ensnarer RJ: Bronchiolitis obliterans and organizing pneumonia associated with ankylosing spondylitis. Arthritis Rheum 1994;37:1557-1559.

244 Richly DJ, Dipper JT: Infections associated with tumor necrosis factor- $\alpha$ antagonists. Pharmacotherapy 2005;25:1181-1192.

245 Scobie BA: Disturbed oesophageal manometric responses in patients with ankylosing spondylitis and pulmonary aspergilloma. Australas Ann Med 1970;19:131-134.

246 Berdal G, Halvorsen S, van der Heijde D, Mowe M, Dagfinrud H: Restrictive pulmonary function is more prevalent in patients with ankylosing spondylitis than in matched population controls and is associated with impaired spinal mobility: a comparative study. Arthritis Res Ther 2012;14:R19.
247 Fournié B, Boutes A, Dromer C, Sixou L, Le Guennec P, Granel J, Railhac JJ: Prospective study of anterior chest wall involvement in ankylosing spondylitis and psoriatic arthritis. Rev Rhum Engl Ed 1997;64:22-25.

248 Brambila-Tapia AJ, Rocha-Muñoz AD, Gonzalez-Lopez L, Vázquez-Del-Mercado M, Salazar-Páramo M, Dávalos-Rodríguez IP, De la Cerda-Trujillo L, Diaz-Toscano ML, Hernandez-Cuervo P, Diaz-Rizo V, Sanchez-Mosco D, Vazquez-Jimenez JC, Cardona-Muñoz EG, Gamez-Nava JI: Pulmonary function in ankylosing spondylitis: association with clinical variables. Rheumatol Int 2013;33:2351-2358.

249 Fortoul TI, Cano-Valle F, Oliva E, Barrios R: Follicular bronchiolitis in association with connective tissue diseases. Lung 1985;163: 305-314.

250 Ho HH, Lin MC, Yu KH, Wang CM, Wu YJ, Chen JY: Pulmonary tuberculosis and disease-related pulmonary apical fibrosis in ankylosing spondylitis. J Rheumatol 2009;36: 355-360.

251 Momeni M, Taylor N, Tehrani M: Cardiopulmonary Manifestations of Ankylosing Spondylitis. Int J Rheumatol 2011;2011: 728471 